If you no longer need this publication write to the Geological Survey in Washington for an official mailjng label to use in returning it

UNITED STATES DEPARTMENT OF THE INTERIOR

CHARACTERISTIC

MARINE JURASSIC FOSSILS FROM THE WESTERN INTERIOR OF THE UNITED STATES

GEOLOGICAL SURVEY PROFESSIONAL PAPER 214-B 


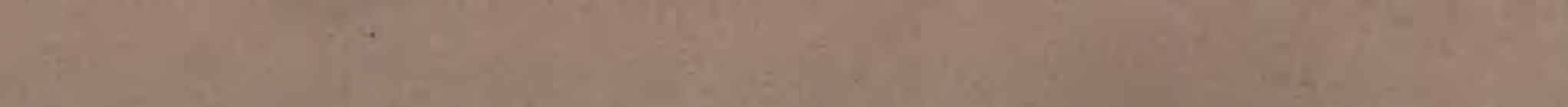

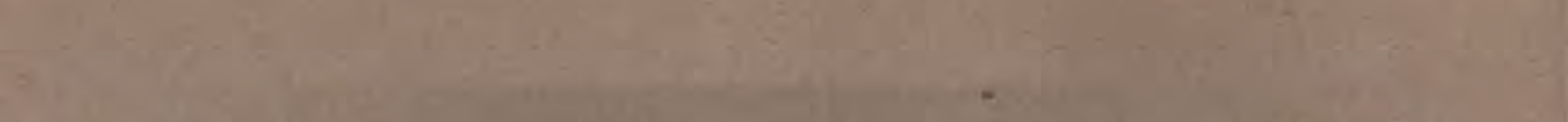

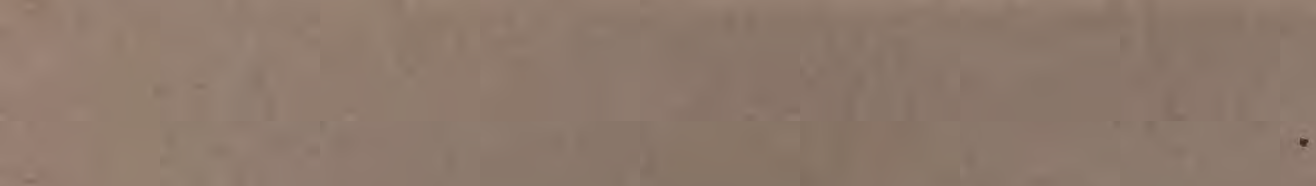
क्ष

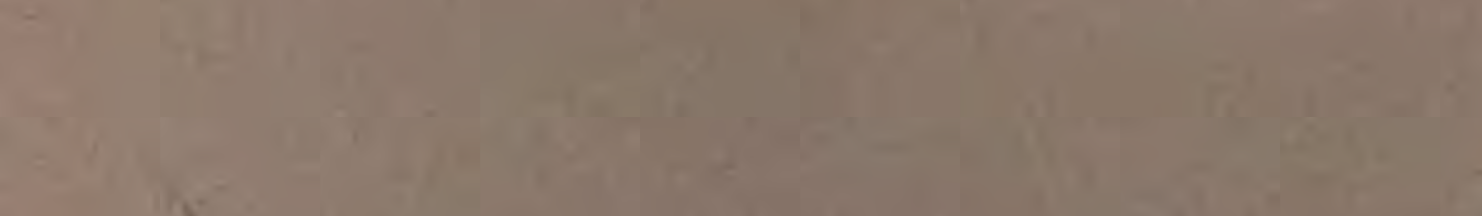

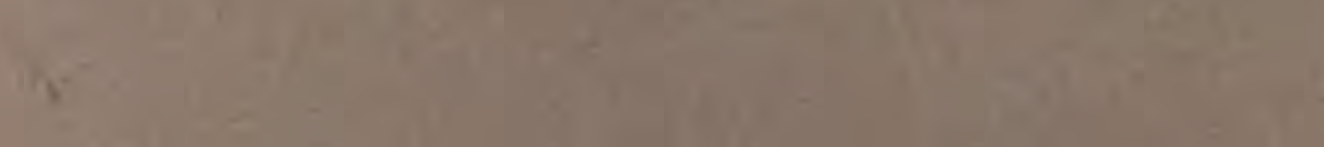

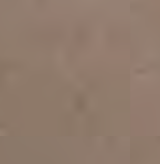


UNITED STATES DEPARTMENT OF THE INTERIOR

J. A. Krug, Secretary

GEOLOGICAL SURVEY

W. E. Wrather, Director

Professional Paper 214-B

\section{CHARACTERISTIC MARINE JURASSIC FOSSILS FROM THE WESTERN INTERIOR OF THE UNITED STATES}

BY

RALPH W. IMLAY

Shorter contributions to general geology, 1947 (Pages 13-33)

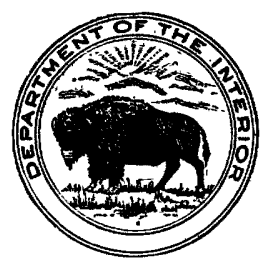

UNITED STATES

GOVERNMENT PRIXTTING OFFICE WASHINGTON : 19.18

For sale by the Superintendent of Documents, U. S. Government Printing Office, Washington 25, D. C. Price 35 cents 


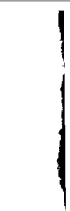




\section{CONTENTS}

\section{ILLUSTRATIONS}

Prate 4. Correlation of Jurassic formations

5-9. Characteristic Jurassic fossils 


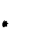




\title{
CHARACTERISTIC MARINE JURASSIC FOSSILS FROM THE WESTERN INTERIOR OF THE UNITED STATES
}

\author{
By R. W. ImLAY
}

\begin{abstract}
The marine Middle and Upper Jurassic rocks in the western interior of the United States contain at least eight faumal zones that may be defined on the basis of their characteristic ammonites. From oldest to youngest they include the zones of Defonticeras-Stemmatoceras, Arctocephalites, Arcticoceras, Gouericeras subitum, Kepplerites ef. $K$. tychonis, Kepplerites melearni, Quenstedtoceras collieri, and Cardioceras cordiforme. The first zone and the zone of Kepplerites ef. $K$. tychonis are provisional and may be divisible faunally; another zone may exist at the top of the marine Jurassic. Descriptions are given of some of the most diagnostic fossils of these zones.
\end{abstract}

\section{INTRODUCTION}

Since publication in 1945 of a brief statement on the occurrence of Middle Jurassic rocks in the western interior of the United States, ${ }^{1}$ the writer has had the opportunity of seeing many typical sections of the Jurassic in all the Rocky Mountain States and of making many fossil collections, which will be the basis for several stratigraphic and paleontologic papers. In order to make some of this information promptly available to field workers, the writer has prepared summary discussions of the various faunas, has noted their stratigraphic positions, and has written descriptions of a few of the most characteristic fossils. Establishment of the faunal succession within the Middle and Upper Jurassic sequence of rocks should be useful in making regional correlations and in deciding what stratigraphic nomenclature will be most appropriate and serviceable locally.

Throughout this paper the phrases United States National Museum and United States Geological Survey Mesozoic locality, are abbreviated to U.S.N.M., and U.S.G.S. Mes. loc., respectively.

\section{FALNAL ZONES AND CORRELATIONS}

Eight ammonite zones have been recognized in the marine Jurassic of the western interior of the United States. From youngest to oldest they may be listed as follows:
Cardioceras cordiforme Quenstedtoceras collieri Kepplerites mrtearni Kepplerites (f. $K$. tychonis
Gowericeras subitum Areticoceras Arctocephalites
Defonticeras-stemmatoceras

${ }^{1}$ Imlay, R. W., Occurrence of Middle Jurassic rocks in western interior of United States: Am. Assoc. Petroleum Geologists Bull, vol 29, pp. 1019-1027, 1945
These do not represent a continuous faunal succession. The Defonticeras-Stemmatoceras beds at the base are not well known and may be divisible faunally. T: are separated from the beds containing Arctocephatites by shale and limestone that may contain other faunas, perhaps corresponding in part to the Cranocephatites beds of east Greenland. ${ }^{2}$ The zones of Arctocephalites, Arcticoceras, Gowericeras, and Kepplerites form a continuous succession. In Montana a disconformity between the zones of Kepplerites mclearni and Quenstedtoceras (Bowrkelamberticeras) collieni represents mos' of the middle and upper Callovian. Farther south the disconformity may be partly filled by the nonfossiliferous Preuss sandstone and Entrada sandstone. The Quenstedtoceras collieri zone is succeeded immediately by the Cardioceras cordiforme zone. Still higher marine beds contain a few cardioceratids that probably. represent a distinct assemblage.

Plate 4 shows the faunal zones and summarizes in compact form many of the relations discussed in the following pages.

\section{Defonticeras-Stemmatoceras Zone}

This provisional zone is represented in the lower part of the Sawtooth formation of western Montana, the middle part of the Gypsum Spring formation of central Wyoming and southern Montana, and the basal part of the Twin Creek limestone of western Wyoming and eastern Idaho. It is characterized by the ammonites Defonticeras, Stemmatoceras, and Zemistephanas? and by numerous pelecypods, of which some have been described by Stanton ${ }^{3}$ and by Warren. Gryphaea planoconvexa Whitfield and $G$. impressimarginata $\mathbf{M c L} \mathbf{L a r n}$ are found associated with the ammonites, although the latter is uncommon. The forms assigned to $G$. impressimarginata differ from typical forms in the Arcto-

\footnotetext{
s Spath, L. F., The invertebrate faunas of the Bathonian-Callovian deposits of Jameson Land (East Greenland) : Meddelelser om Grønland, Bind 87, no. 7 , pp. $138,145,1932$.

${ }^{3}$ Stanton, T. W., Mesozoic fossils, in Geology of the Yellowstone National Park: U. S. Geol. Survey Mon. 32, pt. 2, pp. 600-632, pls. 72-75 (in part), 1899.

4 Warren, P. S., A new pelecypod fauna from the Fernie formetion, Alberta: Royal Soc. Canada Trans., $3 d$ ser., vol. 26, sec. 4, pp. 1-36,
} pls. $1-5,1932$. 
cephalites and Arcticoceras beds only by a somewhat smaller average size and by lesser ventral extension of the ribs.

Defonticeras is the most common ammonite. It was found associated with Stemmatoceras at several localities in the border area of Idaho and Wyoming. It occurs with a stephanoceratid, tentatively assigned to Zemistephanus, in the middle limestone member of the Gypsum Spring formation of the west bank of the Yellowstone River, 21/2 miles south of Livingston, Mont. A specimen identified as Defonticeras oblatum (Whiteaves) ${ }^{5}$ was found 20 feet above the base of the Sawtooth formation at Swift Reservoir, Pondera County, Mont. Fragments questionably assigned to Defonticeras have been found at several localities in the Gypsum Spring formation. Stephanoceratids are less common. In addition to the specimens found near Livingston, mentioned above, a few fragments were obtained on Cinnabar Mountain, near Gardner, Mont., about 43 feet below the main sill and near the middle of the Gypsum Spring formation. About 30 specimens resembling Zemistephanus vancouveri McLearn ${ }^{6}$ were found in the lower part of the Gypsum Spring formation south of Cody, Wyo., in sec. 6, T. 51 N., R. 101 W.

The beds containing Defonticeras and Stemmatoceras have been considered middle or upper Bajocian. ${ }^{7}$ Determination of their exact age must await detailed faunal studies, although their position not far below the Arctocephalites beds suggests that their age is upper Bajocian.

Defonticeras oblatum (Whiteaves), Gryphaea planoconvexa Whitfield, and $G$. impressimarginata McLearn are described and illustrated in this paper.

\section{Arctocephalites Zone}

The ammonite Arctocephalites has been found in the upper silty-to-sandy member of the Sawtooth formation in western Montana, ${ }^{8}$ in similar sandy beds in the Grassy Mountain section near Blairmore, Alberta, ${ }^{9}$ and

${ }^{5}$ Whiteaves, J. F., On the fossils of the coal-bearing deposits of the Queen Charlotte Islands: Canada Geol. Survey, Mesozoic fossils, vol. 1, pt. 3, p. 209, 1876. McLearn, F. H., Contributions to the stratigraphy and palaeontology of Skidegate Inlet, Queen Charlotte Islands, B. C.: Canada Nat. Mus. Bull. 54, p. 16, pl. 15, fig 1, 1929.

${ }^{6}$ McLearn, op. cit., p. 20 , pl. 11, figs. 1,2 .
${ }^{2}$ McLearn, F. H., Some Canadian Jurassic faunas : Royal Soc. Canada Trans., 3d ser., vol. 21, pp. 63, 68, 1927. Crickmay, C. H., Jurassic history of North America : Its bearing on the development of continental structure: Am. Philos. Soc. Proc., vol. 70, no. 1, p. 35, 1931. Spath, L. F., op. cit., p. 11.

${ }^{8}$ Imlay, R. W., Occurrence of Middle Jurassic rocks in western interior of United States: Am. Assoc. Petroleum Geologists Bull., vol. 29, pp. $1024,1025,1945$.

'McLearn, F. H., New pelecypods from the Fernie formation of the Alberta Jurassic: Royal Soc. Canada Trans., vol. 18, sec. 4, pp. 39-61, pls. 1-9, 1924. Buckman, S. S., Jurassic Ammonoidea, in Mesozoic paleontology of Blairmore region, Alberta: Canada Nat. Mus. Bull. 58 . pp. 1-27, pls. 1-3, 1929. in the Harrison Lake area of British Columbia. ${ }^{10}$ In Montana most of the specimens of Arctocephalites were obtained from the upper 10 feet of the upper silty-tosandy member of the Sawtooth formation, but fragments were obtained also from the lower part of the member. Associated with Arctocephalites in Montana are large forms of Procerites, as much as 1 foot in diameter, and many pelecypods. Most of the pelecrpods ${ }^{11}$ have been described by Stanton ${ }^{12}$ and McLear', ${ }^{13}$ but these are not confined to the member. Some of the most characteristic species are Gryphaea impressimarginata McLearn, Corbula munda McLearn, and Eunicrotis ferniensis McLearn. The writer feels that designation of a zonal index fossil should await additional field studies.

The age of the Arctocephalites zone was conaidered lower Callovian by Buckman ${ }^{14}$ and probably upper Bathonian by Spath. ${ }^{15}$ The writer considers that the Arctocephalites beds are of Bathonian age correlative with the lower part of the Cornbrash beds of England. This correlation is based partly on the association of Procerites with Arctocephalites and partly on stratigraphic position beneath beds containing raried ammonite faunas that permit accurate correlation rith the lower Callovian ammonite zones of northwest Jurope. The beds with Kepplerites correlate with the Sigaloceras calloviense zone and the underlying beds with Gowericeras correlate with the Proplanulites koenigi zone, as will be discussed later. The Arcticoceras beds, therefore, occupy the position of the Macrocephalites macrocephalus zone, and the Arctocephalites beds, immediately below, appear to correspond to the Clydoniceras discus zone. A zone characterized by Cranocephalites, as in east Greenland, ${ }^{16}$ has not been recognized in the western interior region, contrary to recent statements by the writer, ${ }^{17}$ who misidentified a specimen of $D e$ fonticeras, but the zone may yet be found in the middle part of the Sawtooth formation.

Arctocephalites sawtoothensis Imlay and A. metastatus (Buckman) var. sweetgrassensis Imlay are described and illustrated in this paper.

\section{Areticoceras Zone}

An ammonite zone characterized by Arcticoceras, previously recorded only from East Greenland ${ }^{18}$ and

${ }^{10}$ Crickmay, C. H., Fossils from Harrison Lake area, British Columbia : Canada Nat. Mus. Bull. 63, pp. 39, 60, 63, pls. 18-20, 1930.

11 Imlay, R. M., op. cit., p. 1024.

${ }^{12}$ Stanton, T. W., op. cit., pp. 600-632, pls. 72-75 (in part).

${ }^{13}$ McLearn, F. H., op. cit., 1924.

14 Buckman, S. S., op. cit.

${ }^{16}$ Spath, L. F., op. cit., pp. 14, 33, 36, 144, 145.

${ }^{16}$ Spath, L. F., op. cit., pp. 138, 144, 145.

${ }^{17}$ Imlay, R. W., op. cit., p. 1024.

${ }^{18}$ Spath, L. F., op. cit., pp. 138, 142, 145. 
the Petchora Basin of northern Russia, ${ }^{19}$ has now been identified at a number of widely separated localities in the western interior region of the United States, including the following:

1. Basal sandstone and shale of the Sudance formation in the Black Hills area, South Dakota and Wyoming.

2. Basal sandstone of the Sundance formation in the Hartville uplift, eastern Wyoming.

3. Basal shaly limestone of the Sundance formation near Cody, north-central Wyoming.

4. Basal shale of the Rierdon formation in the Little Rocky Mountains, north-central Montana.

5. Basal shale of the Rierdon formation in the Sawtooth Range, northwestern Montana.

6. Basal shale of the Rierdon formation in the Yellowstone National Park area.

Arcticoceras is associated with Cadoceras and Procerites in the Little Rocky Mountains and the Sawtooth Range of Montana and with small forms of Arctocephalites in the Hartville uplift of Wyoming. Pelecypods are common at some localities, but most of the species appear to range beyond the Arcticoceras zone. Gryphaea impressimarginata McLearn attains its greatest development in the Arcticoceras zone in the Sawtooth Range and does not range above that zone. The writer considers that not enough is known about the fauna of the Arcticoceras zone to designate a zonal index.

The age of the Arcticoceras beds of Greenland and Russia was determined by Spath ${ }^{20}$ as lower Callovian. In Greenland the Arcticoceras beds contain Cadoceras and probably Pleurocephalites associated with the more abundant Arcticoceras. Some immature Arcticoceras likewise occur in the upper part of the Arctocephalites beds. ${ }^{21}$ Other specimens of Arcticoceras are associated with Kepplerites in one collection, but Spath ${ }^{22}$ thinks they are possibly from a different horizon. In the Petchora Basin of northern Russia, Arcticoceras is associated with Pleurocephalites krylowi (Milachewitch)..$^{23}$ In central Russia near Sergatsch, southwest of Gorki (Nijni Novgorod), P. krylowi is associated with $C a d o$ ceras elatmae Nikitin and certain perisphinctids ${ }^{24}$ that Spath ${ }^{25}$ refers questionably to the Callovian genus

\footnotetext{
${ }^{19}$ Keyserling, A. Graf, Wissenschaftliche Beobachtungen auf einer reise in das Petschora-Land in Jahre 1843, p. 331, 1846. Sokolov, D. N. Zur Ammoniten-Fauna des Petschoraschen Jura : Mém. Com. Géol., nouvelle sér., livr. 76, pp. 15, 49, St. Pétersbourg, 1912.

20 Spath, L. F., The invertebrate faunas of the Bathonian-Callovian deposits of Jameson Land (East Greenland) : Meddelelser om Grønland, Bind 87, no. 7 , pp. 141, 142, 1932 .

${ }_{21}$ Spath, L. F., op. cit., p. 132.

22 Idem, p. 127.

${ }^{23}$ Milachewitch, C., Etudes sur les couches a Ammonites macrocephalus en Russie: Soc. Impérial Moscou Bull., p. 14, pl. 1, figs. 1a-c, 1879. Sokolov, D. N., op. cit., pp. 14, 19.

24 Milachewitch, C., op. cit., p. 8.

${ }^{25}$ Spath, $\mathrm{L}$. F., Revision of the Jurassic cephalopod fauna of Kachh (Cutch) : Palaeontologia Indica, new ser., vol. 9, Mem. 2, pt. 4, p. 312, 1931.
}

Kinkeliniceras. At several places in central Russia, ' Cadoceras elatmae is associated with species of Gowericeras, Chamoussetia, and Macrocephalites, ${ }^{28}$ which is clearly a lower Callovian assemblage. Arkell ${ }^{27}$ shows that the zone of $C$ adoceras elatmae in Russia is equivalent to the zones of Macrocephalites macrocephalus and Proplanulites koenigi in northwest Europe.

The Arcticoceras zone in the western interior of the United States corresponds to the Macrocephalites $m a$ crocephalus zone of northwest Europe, for the immediately overlying beds in America contain abundant Gowericeras and appear to correspond to the Gowericeras goweri beds (Proplanulites koenigi zone) of Europe. The absence of Gowericeras in the collections from East Greenland undoubtedly influenced Spath ${ }^{28}$ in correlating the Arcticoceras beds with the Gowericeras goweri beds of England. The presence of $F \times 0$ cerites in the Arcticoceras zone is interesting, as Procerites, while normally characteristic of the Bathonian; has been found in the lower Callovian of the Mediterranean region. ${ }^{29}$

There remains the possibility that both the Arcticoceras and Arctocephalites zones are equivalent to the Macrocephalites macrocephalus zone of Europe. T $\mathrm{T}^{\mathrm{T}}$ is seems unlikely, in view of the thickness of the Arcticoceras beds, which locally attains 60 feet, and because the Arctocephalites beds in places lie only about 100 feet above the Defonticeras beds of Bajocian age.

Arcticoceras codyense Imlay and Cadoceras shoshonense Imlay are described and figured in this paper.

\section{Gowericeras subitum Zone}

This zone is characterized by many species and individuals of Gowericeras and Cadoceras, the latter attaining sizes of more than 1 foot in diameter. Other ammonites include rare specimens of Procerites, Grossouvria, and Arcticoceras. Pelecypods are abundant, large naticoid gastropods are fairly common, and wellpreserved brachiopods occur locally. Gryphaea nebrascensis Meek and Hayden appears in abundance at the base of the zone and ranges upward to the top of the marine Jurassic. The characteristic fossils of the zone have been found at many localities in Montana and northern Wyoming.

The Gowericeras beds are correlated with the Prnplanulites koenigi zone of northwest Europe on the br.sis

${ }^{26}$ Nikitin, S. N., Die Cephalopodenfauna der Jurabildungen des Gouvernements Kostroma: Russ. K. Min. Gesell. Verh., Band 20, ser. 2, p. $84,1884(1885)$.

${ }^{27}$ Arkell, W. J., Standard of the European Jurassic : Geol. Soc. America Bull., vol. 57, p. 25, 1946.

${ }^{2}$ Spath, L. F., The invertebrate faunas of the Bathonian-Callcvian deposits of Jameson Land (East Greenland) : Meddelelser om Grøn?and, Bind 87, no. 7 , pp. 131, 145, 1932.

${ }^{29}$ Spath, L. F., Revision of the Jurassic cephalopod fauna of Kachh (Cutch) : Palaeontologia Indica, new ser., vol. 9, mem. 2, pt 4, p. 281, 1931. Neumayr, M., Die Cephalopoden-Fauna der Oolfthe von Balin bei Krakau : Geo. Reichsanstalt Wien, Abh., Band 5, Heft 6, pp. 39-41, 1871. 
of the abundance of Gowericeras, the resemblance of several species to Goucriceras in the Kellaways beds of Great Britain, the highest occurrence of Prorerites, and stratigraphic position about 90 feet below beds containing Kepplerites, Sigaloceras, and Kamptohepha7ites.

Gowericeras subitum. Imlay and Gryphaea nebrascensis Meek and Hayden are described and illustrated in this paper.

\section{Kepplerites cf. K. tychonis Zone}

This is a provisional zone at least partly representing the 80 to 90 feet of beds between the Gowericeras subitum zonne and the Kepplerites mclearni zone. It is characterized by a densely ribbed species of Kepplerites similar to $K$. tychonis (Ravn) ${ }^{30}$ from East Greenland and unlike any of the six known species in the $\boldsymbol{K} \rho \mathrm{ppler-}$ ites melearni zone in Montana. Associated fossils are Cadoceras, Gryphaea nebrascensis Meek and Harden, and various pelecypods.

The presence of a finely ribbed Kepplerites comparable with Kepplerites tychonis (Rarn) and unlike any species in the Kepplerites mclearni zone suggests correlation with the $\boldsymbol{K}$. tychonis beds of East Greenland. Likewise the association with $C$ adoceras is comparable with that in the $K$. tychonis beds, where Cadoreres and Kepplerites occur together in abundance and contrasts with the nonassociation of these genera in the Govericeras subitum and $K$ epplerites mclearni zones. Of course, this may reflect some local condition and not have any special significance regionally, considering that both genera in Europe occur as low as the Cornbrash beds and range into the middle Callovian.

The age of the Kepplerites tychonis beds of East Greenland has not been determined exactly. Spath ${ }^{31}$ indicates a correlation with the zone of Sigaloceras calloviense but discusses the possibility of the beds being as high as middle Callovian. He was considerably influenced by the presence of Gulietmiceras. ${ }^{32}$ a subgenus of Cosmoceras, which first appears in the Sigaloceras calloviense zone but is most common in the Cosmoceras jason and Erymoceras coronatum zones.

The age of the beds containing $K$ epplerites cf. $\boldsymbol{K}$. $t y$ chonis in the western interior region is detelmined by stratigraphic position to be lower Callovian. probably corresponding to the lower part of the sigaloceras calloviense zone.

Kepplerites (Seymourites) cf. $\boldsymbol{K}$.tychonis (Ravn) is described and illustrated in this paper.

\footnotetext{
${ }^{30}$ Ravn, J. P. J., On Jurassic and Cretaceous fossils from northeast Greenland: Meddelelser om Grønland, Bind 45, p. 490, pl. 37, fig. 1. 1911. Spath, L. F., The invertebrate faunas of the Bathonian-Callovian deposits of Jameson Land (East Greenland) : Meddelelser om Gronland. Bind 87. no. 7 , pp. $83-87$, pl. 23 , figs. $1-3$ : pl. 24, figs. $2,4,6$; pl. 25 , figs. $1-3$ : pl. 26, figs. 3, 6, 1932 .

${ }^{31}$ Spath, I. F., op. cit., pp. 145,146

${ }^{32}$ Spath, L. F., op. eit., p. 96 , pl. 24 , figs. 3a, b; pl. 26 , fig. 5
}

\section{Kepplerites mclearni Zone}

This zone has been identified in Montana at the top of the Rierdon formation in the Little Rocky Mountains, the Bearpaw Mountains, the East. Butte of the Sweetgrass Hills, the south edge of Glacier I'Tational Park along the Great Northerm Railway, and in the Big Snowy Mountains. It is absent in the Little Belt Mountains, most of the Sawtooth Range, and much of southwestern Montana, owing to erosion or nondeposition in middle or upper Callovian time. It is probably represented in the upper part of the Yakoun formation of British Columbia by various species of Kepplerites, ${ }^{3}$ and it is probably present in the Twin Creek limestone of Idaho and western Wyoming.

The zone is characterized by an abundance of species and individuals of Kepplerites belonging to the subgenus Seymourites. Other ammonites are un`ommon but include at least two species of $K$ amptokephalites, one species of Macrocephatites, two species of Sigaloceras, and one species of Grossourria. In addition one specimen of Cosmoceras (Gutielmites) from the highest unit of the Rierdon formation in the Sage Creek section of the Sweetgrass Hills probably belongs in the zone, although Kepplerites was not obtained with Gulielmites at that locality. The zone also contains many pelecypods, including Gryphaea nebrascensis Meek and Hayden, and locaHy some brachiopods.

The lower Callovian age of the Kepplerites melearni zone seems evident on the basis of the ammonites. Macrocephatites and Kamptokephatites are probably not younger than the lower Callovian, Grossouvria is certainly not older, and Sigaloceres is typical. In Europe Cosmoceras (Guliclmites) characterizes the zone of Cosmoceras jason but has been recorded from the upper part of the sigaloreras calloviense zone. ${ }^{34}$ This faunal evidence, plus the stratigraphic position of the $K e p$ plerites mclearni zone above the Gowericeras subitum zone of lower Callovian age, furnishes strong argument for correlating the Kepplerites mclearni zone with the Siguloceras callowiense zone of northwest Europe. The evidence would be even stronger if the isolated specimen of Gulielmites from the Sweetgrass Hills shovld prove to come from a higher level than the other ammonites in the $\pi$. melearni zone.

Kepplerites (Seymourites) melearni Imlay is described and illustrated in this paper.

\section{Quenstedtoceras collieri Zone}

This zone has been identified faunally only in the Little Rocky Mountains and the Bearpaw Mountains of

\footnotetext{
33 McLearn, F. H., Contributions to the stratigraphy and raleontology of Skidegate Inlet, Queen Charlotte Islands, B. C.: Canade Nat. Mus. Bull, 54, pp. 4-12, 1929.

34 Spath, L. F., Revision of the Jurassic cephalopod faun of Kachh (Cutch): Palaeontologia Indica, new ser., vol. 9, mem. 2, p ${ }^{+} .6$, p. 857 , 1933.
} 


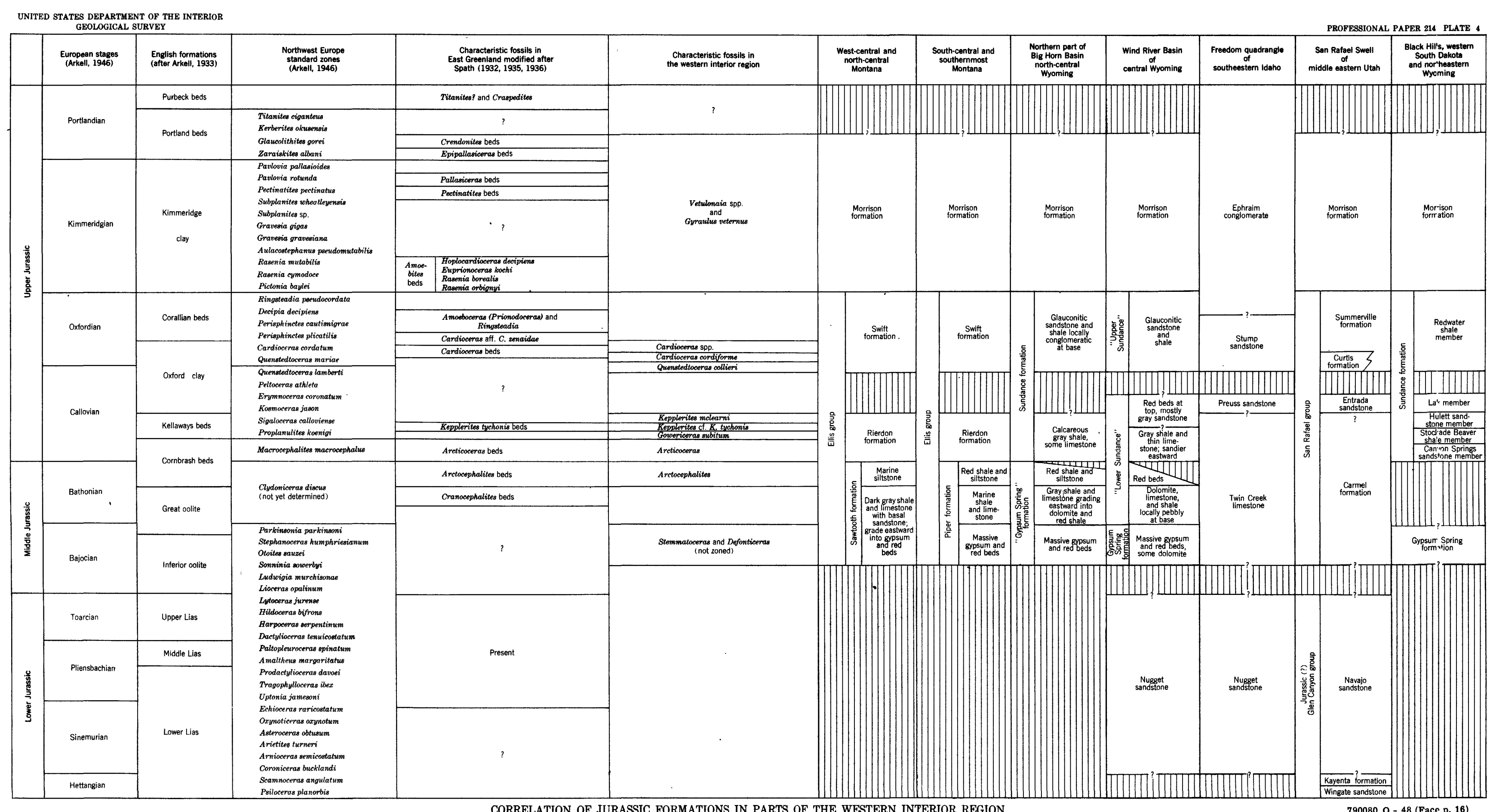


north-central Montana in concretion beds from 20 to 30 feet above the base of the Swift formation, directly beneath shales containing Cardioceras cordiforme (Meek and Hayden) and associated species of Cardioceras. Failure to find the zone elsewhere may be explained in part by the sandy character of beds at that stratigraphic position in many parts of the western interior. Also, in places the zone may not be represented by sediments, as at Red Dome on the west side of the Pryor Mountains in south-central Montana, where sandstone containing $C a r$ dioceras rests directly on the Rierdon formation.

The common ammonites in the Quenstedtoceras collieri zone are Quenstedtoceras (Bourkelamberticeras) collieri Reeside and Q. (Pavloviceras) n. spp. Rare ammonites include Prososphinctes n. sp., Cardioceras (Maltoniceras) sundancense Reeside, $C .(M$.$) n. sp., and$ C. (Scarburgiceras) n. sp. Pelecypods are common but mostly undescribed. Gryphaea nebrascensis Meek and Hayden is abundant. Belemnites are common in silty shales, as is true locally for other units of the marine Jurassic.

The Quenstedtoceras collieri zone probably corresponds to the upper part of the $Q$. lamberti zone and the lower part of the $Q$. mariae zone of Europe, because of the abundance of Bourkelamberticeras, which subgenus is typical of the $Q$. lamberti zone but ranges into the $Q$. mariae zone, and because Pavloviceras and Scarburgiceras are characteristic of the $Q$. mariae zone and are not known below the upper part of the $Q$. lamberti zone.

This age determination means that in the Little Rocky Mountains and in the Bearpaw Mountains the Swift formation is separated from the underlying Rierdon formation by an unconformity representing most of the middle and upper Callovian and corresponding to the European zones of Cosmoceras jason, Erymnoceras coronatum, and Peltoceras athleta.

Quenstedtoceras (Bourkelamberticeras) collieri Reeside is described and illustrated in this paper.

\section{Cardioceras cordiforme Zone}

This zone has been identified at many places in the western interior region, in the Stump sandstone of Idaho and western Wyoming, the Curtis formation of Utah, the Swift formation of Montana, the Redwater shale member of the Sundance formation in the Black Hills area of South Dakota and eastern Wyoming, and in equivalent beds in central Wyoming. It generally occurs near the top of the lower third or half of these units but in places occurs near the base. In the Little Rocky Mountains and in the Bearpaw Mountains it occurs directly above the zone of Quenstedtoceras col7ieri. It is characterized by the abundance of Scarburgiceras, a subgenus of Cardioceras, and associated species of Goliathiceras and Pachycardioceras. Cardio- ceras (Scarburgiceras) cordiforme (Meek and Hayder) and $C$. (S.) wyomingense Reeside are the most common species. Associated subgenera of Cardioceras include Scoticardioceras, Subvertebriceras, Cardioceras, Mattoniceras, Vertebriceras and Sagitticeras. In Europe the first three subgenera occur as low as the $Q$. mariae zone, but the last three have not been found below t] $e$ $C$. cordatum zone, according to any records examined by the writer. Scarburgiceras ranges from the uppor part of the $Q$. lamberti zone into the base of the $C$. cordatum zone. Goliathiceras is reported most frequently from the $C$. cordatum zone, although the subgenus Pachycardioceras occurs as low as the $Q$. marixe zone. Judging from these European ranges the zone of Cardioceras cordiforme would represent the upper part of the $Q$. mariae zone and the basal part of the $C$. cordatum zone. A suggestion that Cardioceras cordiforme does not range above the $Q$. mariae zone is furnished by a grossouvrid resembling Grossouvria (Poculisphinctes) trina (Buckman), ${ }^{35}$ occurring in the sare bed with $C$. cordiforme, 1 mile north of Redwater Creek, about 9 miles northwest of Spearfish, Butte County, S. Dak. In Europe, Poculisphinctes has bern recorded most commonly from the $P$. athleta and $Q$. lamberti zones and rarely from the $Q$. mariae zora. Evidently more field work is necessary to determine the upper limit of the Cardioceras cordiforme zone and whether a still higher zone can be recognized in America in the marine Jurassic.

Cardioceras (Scarburgiceras) cordiforme (Meek and Hayden) and other species of this zone have been described and illustrated by Reeside ${ }^{36}$ and are not refigured in this paper.

\section{SYSTEMATIC DESCRIPTIONS • \\ Gryphaea planoconvexa Whitfield}

Plate 5, figure 6

Gryphaea planoconvexa Whitfield, in Ludlow, Wm., Rept. Recon. naissance Carroll, Montana, to the Yellowstone National Park, p. 142, pl. 2, figs. 9, 10. Washington, 1876.-Stanton, U. S. Geol. Survey Mon. 32, pt. 2, p. 611, pl. 72, figs. 9, 10 , 1899.

This species is characterized by its subcircular outline, prominent narrow beak, and moderate inflation of the left valve. These features distinguish it easily from any other Gryphaea in the Jurassic of North America. Among European species it resembles the flat variety of G. dilatata Sowerby figured by Arkell ${ }^{37}$ but appears to have a more regular form and a narrower, less incurved beak.

\footnotetext{
${ }^{35}$ Buckman, S. S., Yorkshire type ammonites, vol. 4. pl. 332, 1922.

${ }^{36}$ Reeside, John B., Jr., Some American Jurassic ammonites of the genera Quenstedticeras, Cardioceras, and Amoeboceras, Family Cardio ceratidae: U. S. Geol. Survey Prof. Paper 118, 1919 [1920].

${ }^{37}$ Arkell, W. J., A monograph of British Corallian Lamellibranchla : Paleont. Soc. Pub., pp. 160-170, pl. 20, figs. 1, 2, 5, 6, 1932.
} 
Plesiotype: U.S.N.M. 104138.

Sawtooth and Piper formations and Twin Creek limestone. G. planoconvexa Whitfield has been recorded at many places in the Yellowstone National Park area and in the nearby mountains in Montana, Wyoming and Idaho. All occurrences that the writer has checked are in the middle part of the Sawtooth formation or the Piper formation or the basal limestone beds of the Twin Creek limestone. It is rarely associated with $G$. impressimarginata McLearn, ${ }^{38}$ although this may be explained by differences in facies. It has been found associated with Defonticeras on the Lower Canyon of the Yellowstone River near Livingston, Mont., and with stephanoceratids on Cinnabar Mountain near Gardner, Mont. Easily accessible occurrences in the middle part of the Piper formation are (1) on the Benbow Mill road about 30 miles southwest of Columbus, Mont., sec. 16, T. 5 S., R. 16 E.; (2) on the west side of Boulder River about 20 miles southwest of Big Timber, Mont., in sec. 23, T. 3 S., R. 12 E.; (3) on the north side of Rocky Creek Canyon about 7 miles southeast of Bozeman Court House, in sec. 19, T. 2 S., R. 7 E., Mont.; and (4) on the west side of the Yellowstone River about $2 \frac{1}{2}$ miles south of Livingston, Mont. The best-preserved specimens have been obtained on the north wall of Indian Creek in sec. 20, T. 8 S., R. 2 E., in the Madison Range, Mont.

\section{Gryphaea impressimarginata McLearn}

Plate 5, figures 9-11

Gryphaea impressimarginata McLearn, Royal Soc. Canada Trans., vol. 18, sec. 4, p. 44, pl. 4, figs. 1-5, 1924.

Gryphaea cadominensis Warren, Royal Soc. Canada, Trans., vol. 26, sec. 4, p. 17, pl. 3, figs. 1-4, 1932.

Gryphaea impressimarginata McLearn was described on the basis of small to medium-sized specimens from the Arctocephalites beds in the Blairmore area, Alberta, Canada. It was distinguished from $G$. nebrascensis Meek and Hayden by its more robust form and by the rather coarse ribbing on its umbo. G. cadominensis Warren was described on the basis of small specimens from the Defonticeras beds in the Cadomin area, Alberta: It was distinguished from $G$. impressimarginata by being less trigonal in outline. In the Sawtooth Range of western Montana, G. impressimarginata occurs in abundance in the Arctocephalites zone at the top of the Sawtooth formation and in the Arcticoceras zone at the base of the Rierdon formation. It is absent in the overlying Gowericeras zone, where $G$. nebrascensis first appears in abundance. It is uncommon in the dark shale in the lower part of the Sawtooth formation, probably owing to an unfavorable sedimentary facies. In eastern Idaho, westernmost Wyoming, and north-central

${ }^{38}$ McLearn, F. H., New pelecypods from the Fernie formation of the Alberta Jurassic: Royal Soc. Canada Trans., vol. 18, sec. 4, pp. 44, 1924.
Utah, G. impressimarginata is common in the lower part of the Twin Creek limestone in association vith $D e$ fonticeras and Stemmatoceras. Some of the immature forms appear to be identical with $G$. cadominensis, but the adult forms are indistinguishable from $G$. impressimarginata. The large number of specimens a vailable shows that $G$. impressimarginata varies considerably in shape and ornamentation. Its outline rangis from elongate to ovate to subtrigonal and its convexty from moderate to strong. The coarse radial ribs may be confined to the umbo or may extend to the ventral margin. The beak, when well-preserved, is pointed and generally deflected posteriorly. In some specimens this posterior deflection is very pronounced and in others scarcely noticeable. An inflected area along the postero-dorsal margin is present on most specimens, but a sulcus on the post-umbonal slope is rather uncommon. The right valve is concave and does not have radial ribs. Plesiotypes: U.S.N.M. 104139.

Sawtooth formation and Arcticoceras beds in the basal part of the Rierdon formation in the Sawtooth Range of western Montana. Twin Creek limestone, basal part, in westernmost Wyoming, easterr Idaho, and north-central Utah.

\section{Gryphaea nebrascensis Meek and Hayden \\ Plate 5, figures 7, 8}

Gryphaea calceola var. nebrascensis, Meek and Hayd?n, Acad. Nat. Sci. Philadelphia Proc. for 1861, pp. 437-43), 1861.Smithsonian Cont. Knowledge, vol. 14, art. 5, pp. 74-76, pl. 3, figs. 1a-e and annexed cuts, 1865.

Gryphaea calceola (Quenstedt?) Meek in Simpson, Rept. Expl. Great Basin Terr., Utah, p. 356, pl. 3, fig. 2, 1876.

Gryphaea calceala var. nebrascensis Meek and Hayd'n. Hall and Whitfield, U. S. Geol. Expl. 40th Par. Rept., vol. 4, pt. 2, pp. 286, 287, pl. 7, fig. 11, 1877.-Whiteaves, Canad' भn Naturalist, vol. 8, new ser., no. 7, p. 401, 1878.-Whiteares, Canada Geol. Survey Rept. Progress for 1876-1877, p. 151, 1878Whitfield, Paleontology of the Black Hills, in Nerton and Jenny, Geology and resources of the Black Hills of Dakota : U. S. Geog. and Geol. Survey Rocky Mtn. Region Rept., pp. 349,350 , pl. 3, figs. 13-16, 1880.

Gryphaea nebrascensis Meek and Hayden. Whiteaves, Canada Geol. Survey, Mesozoic fossils, vol. 1, pt. 3, pp. 244, 245, pl. 32 , figs. 2, 2a, 2b, 1884.

Gryphaea calceola var. nebrascensis Meek and Hayden. White, U. S. Geol. Survey 4th Ann. Rept. for 1882-1883, p. 290, pl. 35, figs. 1-5, 1884.-Stanton, U. S. Geol. Survey Mon. 32, pt. 2 , p. 612 , pl. 72, figs. 5-7, 1899.-Butler, U. S. Geol. Survey Prof. Paper 111, pl. 10, figs. 6, 7, 1920.

Gryphaea nebrascensis Meek and Hayden. Arkell, Cotteswold Naturalists' Field Club Proc., vol. 25, pt. 1, p. 61, text figs. 1-5. Gloucester, 1933.

This species is characterized in the adult by its elongate shell, prominent, narrow umbo, strongly incurved beak, generally well-defined sulcus on the posterior side, and especially by the presence of distinct, rodiating striae on the umbonal region. Its considerable resem- 
blance to Gryphaea calceola Quenstedt from the lower Bajocian of Württemberg was noted by Meek and Hayden in their original description. A similar species occurs in the Callovian of Oaxaca, Mexico. The only similar species in the western interior region is $G$. impressimarginata McLearn, which is distinguished by its stouter form, presence of ribs instead of striae on its umbo, and its less incurved beak, which is commonly deflected posteriorly. Some of the stouter forms of $G$. nebrascensis may resemble the more slender forms of G. impressimarginata but are generally distinguished easily by their finer umbonal markings. In these two species, immature forms of less than half an inch in height are very similar.

The specimen herein illustrated is one of the largest and best-preserved in the collections of the Geological Survey and is typical of the species.

Plesiotype: U.S.N.M. 104136.

Gryphaea nebrascensis Meek and Hayden appears in abundance in the Gowericeras subitum zone and ranges to the top of the marine Jurassic. Locally it may be abundant, or it may be absent from beds that are within its vertical range. Some specimens from the Sawtooth formation of western Montana previously identified as $G$. nebrascensis are now considered immature forms of $G$. impressimarginata McLearn. The presence of $G$. nebrascensis generally denotes beds younger than the Arcticoceras zone at the base of the Rierdon formation and the Sundance formation. However, a few specimens of $G$. nebrascensis have been found in the upper part of the Arcticoceras zone at several localities.

\section{Defonticeras oblatum (Whiteaves)}

Plate 5, figures 1-5

Ammonites loganianus (?) Form A, Whiteaves, Canada Geol. Survey, Mesozoic fossils, vol. 1, pt. 1, p. 29, pl. 4, figs. 2, 2a, 1876.

Stephanoceras oblatum (Whiteaves), Canada Geol. Survey, Mesozoic fossils, vol. 1, pt. 3, p. 209, 1884.

Defonticeras oblatum (Whiteaves), McLearn, Canada Nat. Mus. Bull. 54, p. 16, pl. 15, fig. 1, 1929.

The specimen figured herein was first placed in Cranocephalites ${ }^{39}$ because its scaphitoid body chamber and ornamentation resembled that of certain species from Greenland, such as Cranocephalites inversus Spath,40 and because it occurred only about 120 feet below silty beds containing Arctocephalites. However, after the details of the suture had been plotted, the relationships with Defonticeras were clearly seen, as shown by the wide, irregularly bifid second lateral lobe, which is in

\footnotetext{
39 Imlay, R. W., Occurrence of Middle Jurassic rocks in western interior of United States: Am. Assoc. Petroleum Geologists Bull., vol. 29, p. $1024,1945$.

40 Spath, L. F., The invertebrate faunas of the Bathonian-Callovian deposits of Jameson Land (East Greenlaud) : Meddelelser om Grønland, Bind 87, no. 7, p. 25, pl. 5, figs. 2a, b; pl. 6, figs. 7a, b, 1932.
}

marked contrast to the narrow, trifid second lateral lobe of $C$ ranocephalites. The specimen in hand lacks part of the body chamber and has been somewhat crushed. Specific identity with D. oblatum. (Whiteaves)' is shown by the very simple suture line and the abrupt change in character of the ribbing. On the sutured part of the outer whorl the primary ribs are fairly strong, rather closely spaced, and subdivide into two similarly strong secondary ribs. Most of the rib pairs are separated by intercalary ribs. Beginning with the body chamber the primary ribs become rather widely spaced and give rise to pairs of weaker secondary ribs, between which lie single intercalary ribs. None of the other described species of Defonticeras is closely similar.

Plesiotype: U.S.N.M. 104134.

Ellis group, Sawtooth formation. From U.S.G.S. Mes. loc. 19192, about 20 feet above base of Sawtooth formation on north side of Swift Reservoir, sec. $2 i, \mathrm{~T}$. 28 N., R. 10 W., Pondera County, Mont.

\section{Arctocephalites sawtoothensis Imlay, n. sp.}

Plate 6, figure $\tau$

Only the holotype can at present be definitely assigned to this species. It has been compressed laterally in fossilization, but its normal whorl section was probably as wide as high. The flanks and venter are moderately convex. The umbilicus is fairly narrow. The umbilical wall is vertical but rounds rather abruptly into the flanks. The body chamber occupies about threefourths of the last whorl and is terminated by a foirly deep, forwardly projecting constriction.

The posterior end of the outer whorl of the holotype bears fairly strong ribs. The primary ribs curve forward on the lower third of the flank, where some bifurcate, but many remain single. The ribs continue the forward curvature to about the upper third of the $f$ ? nk and then recurve slightly and cross the venter transversely. A number of intercalary ribs arise between the furcation points and the upper third of the flanks. There are about $21 / 2$ times as many secondary ribs as primary ribs. Costation disappears rapidly on the body chamber, most of which is quite smooth except for fine growth lines. The suture cannot be traced.

One small specimen (pl. 6, figs. 2, 5) has very high, sharp ribbing greatly resembling that of the much smaller "Miccocephatites" laminatus Buckman ${ }^{41}$ and may represent an immature form of Arctocephatites sawtoothensis. Its strong primary ribs curve backvaard on the umbilical wall, curve forward on the lower fo"rth of the flanks, and then bifurcate or continue singly in a nearly radial manner. Anteriorly, the anterior brench

41 Buckman, S. S., Jurassic Ammonoidea, in Mesozoic paleontolcgy of Blairmore region, Alberta : Canada Nat. Mus. Bull. 58, p. 14, pl. 1, figs. $4,4 a, 5,1929$. 
SHORTER CONTRIBUTIONS TO GENERAL GEOLOGY, 1947

of each rib pair becomes more or less faintly connected with the primary rib. The ribbing is particularly prominent on the venter.

A. sawtoothensis does not greatly resemble any of the other five species of Arctocephalites known from the Sawtooth formation in Montana. Probably the most similar species is $A$. arcticus (Newton), ${ }^{42}$ which has a smaller umbilicus and loses its ribbing earlier. A. ornatus Spath $^{43}$ has a similar body chamber.

Holotype: U.S.N.M. 104148.

Ellis group, Sawtooth formation, upper silty to sandy member. U.S.G.S. Mes. loc. 19184, at head of Rierdon Gulch, sec. 23, T. 24 N., R. 9 W., Sawtooth Range, Teton County, Mont. The small specimen shown on plate 6, figures 2,5 , was obtained near the base of the upper siltyto-sandy member of the Sawtooth formation about 15 feet above Paleozoic rocks at the head of Lime Gulch, SW1/4 sec. 1, T. 20 N., R. 9 W., Lewis and Clark County, Mont.

Arctocephalites metastatus (Buckman) var. sweetgrassensis Imlay, n. var.

Plate 6, figures 1, 3

The variety is represented in the collections by only one specimen, but was selected for illustration in this preliminary paper because of its close resemblance to "Metacephalites" metastatus Buckman ${ }^{44}$ from the Corbula munda beds in the Fernie formation near Blairmore, Alberta.

The outer whorl of the type is subovate, as wide as high, thickest on lowest part of the flanks, embracing about three-fourths; flanks gently convex, converging gradually into moderately narrow, rounded venter. Umbilicus fairly narrow, wall rounding rather abruptly into flanks. Body chamber not preserved.

The ribbing is fairly strong and somewhat flexuous. The primary ribs are thick, elevated, incline nearly radially on the upper part of the umbilical wall, curve forward rather strongly on the lower third of the flanks, and then bifurcate. The secondary ribs continue the forward curvature to about the middle of the flanks, then become nearly radial and cross the venter transversely. On the middle of the flanks the secondary ribs are slightly weaker than the primary ribs but gradually become higher and thicker toward the venter. Nearly all rib pairs are separated by single intercalary ribs which begin slightly above the furcation points,

\footnotetext{
42 Newton, E. T., and Teall, J. J. H., Notes on a collection of rocks and fossils from Franz Josef Land, made by the Jackson-Harmsworth Expedition during 1894-96: Geol. Soc. London Quart. Jour., vol. 53, p 500 , pl. 40, figs. 1, 1a, 1897. Whitfleld, R. P. Notes on some Jurassic fossils from Franz Josef Land, brought by a member of the Ziegler Exploring Expedition: Am. Mus. Nat. History Bull., vol. 22, p. 131, pl. 18, fig. 2, 1906. Spath, L. F., op. cit., p. 32, pl. 12, fig. 2, 1932.

${ }^{43}$ Spath, L. F., op. cit., p. 39, pl. 8, figs. 3a, b.

4 Buckman, S. S., op. cit., p. 11, pl. 3, figs. 1-4, 1929.
}

are more or less faintly connected with the preceding rib pairs, and are as strong as the forked riks on the upper part of the flanks and on the venter.

The suture line cannot be followed, although, in the type, traces are visible at the anterior end.

The specimen may be slightly compressed, but at a diameter of 73 millimeters the whorl height is 34 millimeters, the whorl thickness 35 millimeters, and the umbilical width 17 millimeters. The last three dimensions expressed as ratios of the diameter are $0.46,0.48$, and 0.23 .

The specimen figured herein agrees' closily with "Metacephalites" metastatus Buckman in ornamentation and whorl proportions. It appears to have a more narrowly rounded venter and less sharp ribbing, but these minor differences may be related to conditions c $f$ preservation. In order to avoid nomenclatorial confusion, it seems preferable to designate the Montana form as a variety until specimens of a similar size can be compared.

Associated with Arctocephalites metastatus Buckman var. sweetgrassensis Imlay are two rathe ${ }^{n}$ similar species. One is distinguished by coarser, sparser ribbing and a broader whorl section. The other has finer ribbing, which is beginning to disappear on the lower parts of the flanks at a diameter comparable with the maximum diameter of the variety $A$. m. sweetgrassensis. Several species from the Arctic region are rather comparable. A. ellipticus Spath ${ }^{45}$ appears to have fewer secondary ribs and a stouter whorl section. A. elegans Spath ${ }^{46}$ has similar ribbing and whorl shape, but has a smaller umbilicus and becomes smooth at an early growth stage. $A$. arcticus (Newton) ${ }^{47}$ has fewer secondary ribs and loses its ribbing earlier. Dolikephalites typicus (Blake) ${ }^{48}$ and Kamptokephalites bedfordensis Spath ${ }^{49}$ show rib curvature similar to that of the variety A.m. sweetgrassensis.

Holotype of variety: U.S.N.M. 104150.

Ellis group, Sawtooth formation, upper silty-tosandy member. U.S.G.S. Mes. loc. 19601, from upper 2 feet of Sawtooth formation on Lonesome Ridge due north of Green Gulch on line of secs. 33 and 34, T. 25 N., R. 9 W., Sawtooth Range, Teton County, $\mathbf{I}^{\text {ront. }}$

\section{Arcticoceras codyense Imlay, n. sp. \\ Plate 6, figures 4, 6, 8}

The holotype has been partly crushed at its anterior end, but the remainder of the shell appears to be nor-

\footnotetext{
45 Spath, L. F., op. cit., p. 33, pl. 13, figs. 6a, b, 1932.

46 Spath, L. F., op. cit., p. 37, pl. 10, figs. 4a, b, 1932.

${ }^{47}$ Newton, E. T., and Teall, J. J. H., op. cit., p. 500, pl. 40, figs. 1, 1 . Whitfield, R. P., op. cit., p. 131, pl. 18, fig 2. Spath, L. F., op. cit., p. 32, pl. 3, fig. 7 ; pl. 12 , fig. 2 , 1932 .

48 Blake, J. F., Fauna of the Cornbrash : Paleont. Soc., p. 42, pl. 3, figs. 1a, b, 1905.

${ }^{40}$ Blake, J. F., op. cit., p. 43, pl. 4, fig. 1. Spath, L. F., Palaeontologia Indica, new ser., vol. 9, mem. 2, pt. 3, p. 172, 1928.
} 
mal. Its form is lenticular, flattened. The whorls are elongate trigonal, much higher than wide, thickest near the umbilicus. The flanks are flattened, the venter narrowly rounded, and the umbilicus nearly closed. The aperture is not preserved, but the body chamber is at least half a whorl in length. The anterior end of the holotype and of two other specimens of comparable size show faint, forwardly inclined ribbing when viewed under oblique lighting. The inner whorls are not known. The adult whorls, represented by several specimens from the Little Rocky Mountains, in Montana, are entirely smooth and have a somewhat stouter whorl shape than the holotype.

The suture is well exposed on the holotype and on two larger specimens. The ventral lobe is wider than lono; first lateral lobe longer than wide and irregularly trifid; second lateral lobe as long as wide and bifid. Saddles much wider than lobes; ventral saddle bifid and its steeply inclined outer slope deeply incised by a secondary lobule; first lateral saddle irregularly bifid, with the outer branch the larger; second lateral saddle broad and of irregular shape.

One specimen from Chalk Butte dome in the Little Rocky Mountains measures about 11 inches (280 millimeters) in diameter.

The dimensions of the types in millimeters and in ratios of the diameter are as follows:

\begin{tabular}{|c|c|c|c|}
\hline Specimen & Diameter & $\begin{array}{l}\text { Whorl } \\
\text { height }\end{array}$ & $\begin{array}{c}\text { Whorl } \\
\text { thickness }\end{array}$ \\
\hline $\begin{array}{l}\text { Holotype, U.S.N.M. 104132 } \\
\text { Paratype, U.S.N.M. 104133a } \\
\text { Paratype, U.S.N.M. 104133b }\end{array}$ & $\begin{array}{r}85 \\
88 \\
181^{*}\end{array}$ & \begin{tabular}{rr|}
51 & $(0.60)$ \\
52 & $(.59)$ \\
110 & $(.60)$
\end{tabular} & $\begin{array}{lr}36 & (0.42) \\
36 & (.40) \\
91 & (.50)\end{array}$ \\
\hline
\end{tabular}

Ammonites referable to Arcticoceras are represented in available collections by about 80 specimens representing at least 6 species. However, a number of fragments cannot be placed in the proper species because of defective preservation, or because the complete development of some species is not known. The various species are distinguishable according to whorl shape, degree of coarseness of ribbing, and loss of ribbing relative to size. All are characterized by a narrowly rounded venter, a very small umbilicus, and by forwardly inclined ribbing in the immature forms. These are the main features that distinguish Arcticoceras from Arctocephalites, ${ }^{50}$ to which the species in question were formerly referred by the writer. ${ }^{51}$ However, a number of species definitely referable to Arctocephalites in the upper silty member of the Sawtooth formation of western Montana are distinguishable from the species herein referred to Arctico-

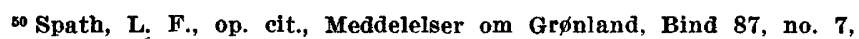
pp. 32-34, 50-63, 1932.

st Imlay, R. W., Occurrence of Middle Jurassic rocks in western interior of United States: Am. Assoc. Petroleum Geologists Bull., 29, pp. 1019-1027. 1945.

$790080-48-3$ ceras by the wider umbilicus, lower and more round ${ }^{\circ} \mathrm{d}$ whorl sections, and nearly radial ribbing. The tranitional character of Arcticoceras between Arctocephalites and Chamoussetia, as pointed out by Spath, ${ }^{52}$ is confirmed by the presence of a slightly pinched venter on one species of Arcticoceras from the basal part of the Rierdon formation in the Sawtooth Range, Mont.

One interesting feature of some of the species of $\mathrm{ArC}$ ticoceras from the western interior region is the cheracter of the second lateral lobe. On the holotype of Arcticoceras henryi (Meek and Hayden) ${ }^{53}$ this lobe is broad and bifid on one side of the shell, but at the same position on the other side it is narrower and trif $x$. Other specimens collected by the writer in the Blark Hills area show that the young forms of $A$. henryi have a trifid second lateral lobe, but that during growth the innermost lobule diminishes in size, and on some adults is completely absent, thereby resulting in a bifid lol 9 . $A$. codyensis likewise has an irregularly bifid second lateral lobe. Specimens of Arcticoceras from the Yellowstone National Park area, placed by Stanton ${ }^{54}$ in Oppelia? sp., include one large form that has a bifid second lateral lobe. An undescribed species from the Sawtooth Range that resembles the Greenland form figured by Madsen ${ }^{55}$ as Macrocephalites ishmae has a trifid second lateral lobe even on the adult whor's, although the inner lobule is smaller than the other tro. A similar irregularly trifid second lateral lobe having a short inner lobule occurs in $A$. kochi Spath, ${ }^{58}$ from East Greenland. The suture line of $A$. ishmae Keyserling, ${ }^{57}$ from Petchora Land in northern Russia, as originally figured is not definitely trifid, but Pompeckj ${ }^{\text {s8 }}$ notes that it was not drawn accurately. The suture of a large specimen of $A$. ishmae as figured by Sokolov ${ }^{59}$ has a trifid second lateral lobe.

Arcticoceras codyensis loses its ribbing at a smal or growth stage than any of the described species of the Arctic region. It has a more narrowly rounded venter than A. henryi (Meek and Hayden), whose whorl siction is comparable with $A$. ishmae (Keyserling).

s2 Spath, L. F., op. cit., pp. 50-52, 1932.

s3 Meek, F. B., and Hayden, F. V., Paleontology of the upper Missorri : Smithsonian Contr. Knowledge, vol. 14, art. 5, pp. 123, 124, pl. 5, fọs. 9a-c, 1865.

st Stanton, T. W. Mesozoic fossils, in Geology of the Yellowstone National Park: U. S. Geol. Survey Mon. 32, pt. 2, pp. 630, 631, 1899.

${ }^{5}$ Madsen, Victor, On Jurassic fossils from East Greenland: Mecdelelser om Grønland, Bind 29, no. 6, p. 191, pl. 8, fig. 7, 1904.

6 Spath, L. F., op. cit., p. 54, 1932.

s7 Keyserling, A. Graf, Wissenschaftliche Beobachtung auf einer Reise in das Petschora-Land in Jahre 1843, p. 331, pl. 20, figs. 8-10, 1846. Roman, Fréderic, Les ammonites jurassiques et crétacées, p. 216, pl. 20 , fig. 204, 1938.

s8 Pompeckj, J. F., The Jurassic fauna of Cape Flora, Franz Josef Land, in Nansen F., The Norwegian North Polar Expedition, 1893-96, Sci. Results, vol. 1, no. 2, p. 72, Christiania, 1900.

${ }^{59}$ Sokolov, D. N., Zur Ammoniten-Fauna des Petschoraschen Jura Com. Géol. Mém., nouvelle sér., livr. 76, pl. 3, fig. 12, St. Pétersbourg, 1912. 
Holotype, U.S.N.M. 104132; paratypes, U.S.N.M. 104133a-c.

The holotype is from a 4-foot bed of nodular to shaly limestone, 7 feet above the base of the Sundance formation (U.S.G.S. Mes. loc..17106) exposed in the south bank of the gorge of the Shoshone River, 2 miles west of Cody, Wyo. Six specimens are from 1 foot of sandy limestone, about 4 feet above the base of the Rierdon formation at the northeast end of Little Warm Dome, Little Rocky Mountains, sec. 32, T. 26 N., R. 26 E., Phillips County, Mont., U.S.G.S. Mes. loc. 19589. The largest specimen was obtained from nodular limestone about 12 feet above the base of the Rierdon formation on Chalk Butte.Dome, Little Rocky Mountains, sec. $\tau$, T. 25 N., R. 26 E., Phillips County, Mont., U.S.G.S. Mes. loc. 19538 .

Cadoceras shoshonense Imlay, n. sp.

Plate 7, figures 13, 16, 17

The species is represented in the collections by at least 26 specimens. It probably includes two large globose specimens measuring about 8 inches in diameter, but the ornamentation of their inner whorls could not be determined.

Form globose, tending to become broader and more nearly spherical during growth. Whorl semicircular in section, wider than high, becoming wider during growth, and embracing most of the preceding whorl. Flanks rounding evenly into the broadly rounded venter. Umbilicus rather narrow; wall vertical at base, steep above, and rounding rather abruptly into flanks. Body chamber apparently nearly complete on the holotype, where it comprises three-fourths of a whorl.

The ribs are coarse and high. On the inner whorls they are as wide as the interspaces, but during growth become narrower than those spaces. The primary ribs are faint on the upper part of the umbilical wall and are weak on the edge of the umbilicus, but become strong ventrally. They curve forward considerably on the lower fourth of the flank and give rise to pairs of secondary ribs that incline forward slightly on the flanks and arch forward gently on the venter. Occasional intercalary ribs begin just above the zone of furcation.

The last suture line of the holotype (pl. 7, fig. 13) is characterized by the shortness of its lobes and saddles. This may reflect the proximity of the body chamber, although a smaller specimen (paratype U.S.N.M. 104144) has several suture lines that are similarly short, and which contrast with those of the other species of $\mathrm{Cado}$ ceras in the Gowericeras beds. Comparable short sutural elements occur in $C$. tschernyschewi Sokolov. ${ }^{60}$

The holotype at a diameter of 74 millimeters has a whorl height of 30 millimeters, a whorl thickness of

oo Sokolov, D. N., op. cit., pp. 19, 51, pl. 1, figs. 2a, b : pl. 2. fig. 1, 1912.
47 millimeters, and an umbilical width of 15 millimeters. A large specimen (U.S.N.M. 104140) that probably represents the same species has the corresponding measurements of 205 millimeters, 100 millimeters, 165 millimeters, and 30 millimeters.

Cadoceras shoshonense is distinguished by its globose form, coarse ribbing, and small umbilicus. Among the associated species of $C$ adoceras that have a similer form the ribbing is considerably finer. The species that approach it in coarseness of ribbing have a more compressed form. None of the described species from Alaska or Canada is closely comparable. Among foreign species, $C$. sublaeve J. Sowerby var. mugosa ${ }^{\text {Spath }}{ }^{61}$ from the Kellaways Rock of England, is probab'y most similar, but has a broader umbilicus, and the rikbing is stronger on the umbilical edge and weaker on the venter. C. freboldi Spath, ${ }^{62}$ from East Greenland, has a different whorl shape and finer ribbing. Cadoceras? sp. indet. Spath ${ }^{63}$ resembles $C$. shoshonense in whorl shape and umbilical width, but its ribbing is different. The rather blunt ribbing of $C$. shoshonense, especially in the young forms, clearly separates it from Pleurocephalites.

Holotype, U.S.N.M. 104143; paratypes, U.S.N.M. 104141, 104144.

U.S.G.S. Mes. locs. 17179 and 19632, from 4 feet of nodular to shaly limestone, 15 feet above base of Sundance formation on south bank of Shoshone Piver 2 miles west of Cody, Wyo. At many localities from nodular sandy limestone in gray shale 10 to 30 feet above base of Rierdon formation in Big Snowy Mountains area, Fergus and Golden Valley Counties. Mont. U.S.G.S. Mes. loc. 19212, from nodular limestone 13 feet above base of Rierdon formation on Chalk Butte. Dome, Little Rocky Mountains, Phillips County, Mont. U.S.G.S. Mes. Loc. 19202, from 10 feet of noduly $r$ limestone about 25 feet above base of Rierdon formstion at the southeast end of the Bearpaw Mountains, Mont. U.S.G.S. Mes. loc. 18718, from Rierdon formation on Lonesome Ridge opposite Green. Gulch, near line of secs. 33 and 34, T. 25 N., R. 9,W., Sawtooth Range, Teton County, Mont. U.S.G.S. Mes. loc. $1960^{\%}$, from 25 to 30 feet below top of Rierdon formation in sec. 21 , T. 25 N., R. 9 W., Sawtooth Range, Teton County, Mont. The species has been found only in the zone of Gowericeras subitum.

\section{Gowericeras subitum Imlay, n. sp.}

Plate 7, figures 1-11

This species is represented in collections in hand by about 55 specimens and is much more common than any of the other 6 associated species of Gowericeras.

\footnotetext{
${ }^{61}$ Spath, L. F., op. cit., p. 60, 1932. Buckman, S. S., Yorkshire type ammonites, vol. 4 , pl. $275,1922$.

${ }^{62}$ Spath, L. F., op. cit., p. 65, pl. 18, figs. 2a, b.

${ }^{63}$ Spath, I. F., op. cit., p. 70, pl. 20, fig. 5 .
} 
The inner whorls are subquadrate, higher than wide, embrace about four-fifths, have flattened flanks that round rather abruptly into a flattened venter, and have a low, steep umbilical wall. During growth the whorls become subovate, wider than high, thickest near the umbilicus, and considerably more evolute; the flanks become gently convex and round evenly into a moderately broad venter; the umbilicus changes from fairly narrow to moderately wide; the umbilical wall becomes moderately high, nearly vertical, and rounds rapidly into the flanks. The body chamber is not completely preserved but is represented by at least half a whorl.

The character of the ribbing changes rather suddenly several times during growth, following a constriction and then an abrupt thickening of the whorl section, but the greatest change occurs at the beginning of the adult body chamber. The smallest whorls (pl. 7, figs. 1, 2, 4) up to a diameter of about 30 millimeters have moderately strong primary ribs that are widely spaced, incline backward slightly on the umbilical wall, incline forward on the lower third of the flank, and terminate abruptly in weak, radially elongate tubercles. From the tubercles arise pairs of secondary ribs that are considerably weaker than the primary ribs. Between successive rib pairs are two or three intercalary ribs that begin between the tubercles and the middle of the flank and are as strong as the paired ribs. The paired and intercalary ribs incline forward on the flanks and cross the venter transversely or with a slight forward bend.

At a diameter of about 30 millimeters the shell has a rather pronounced constriction, which is followed by an abrupt thickening of the whorl section (pl. 7, figs. 5,6 ). Several other constrictions are generally present in the next three-fourths whorl, up to a diameter of about 45 millimeters. The thickening is accompanied by coarsening of the primary ribs, which become relatively much stronger than the secondaries. The primaries terminate in weak radially elongate tubercles from which pass two or three secondaries. Intercalary ribs become less common anteriorly, and generally only one is present between successive groups of branched ribs. The forward inclination of the ribs is very marked, and the secondaries bend forward gently on the venter.

On the body chamber the primary ribs abruptly become much stronger and more widely spaced. The weak radially elongate tubercles persist, but branching occurs well above the tubercles at, or above, the middle of the flanks. For each primary there are three secondaries, of which two are connected with the primary and the other begins high on the flank. All secondary ribs bend forward considerably on the venter and are slightly weaker there than on the flanks.
The suture line (pl. 7, fig. 3) is rather simple. Ventral lobe longer than wide; first lateral lobe trifid, slightly longer than wide, a little shorter than ventral lobe; second lateral lobe trifid, much smaller than first lateral lobe. Saddles wider than lobes; ventral saddle bifid, with largest branch on outer side, as long as wide; first lateral saddle broad and bifid, much smaller than ventral saddle. The tubercle is in the outer branch of the first lateral saddle. Dimensions in millimeters of some of the type specimens are given below. Numl ars in parentheses are ratios of the diameter to the other dimensions :

\begin{tabular}{|c|c|c|c|c|}
\hline Specimen & Diameter & $\begin{array}{l}\text { Whorl } \\
\text { height }\end{array}$ & $\begin{array}{c}\text { Whorl } \\
\text { thickness }\end{array}$ & $\begin{array}{c}\text { Umk illical } \\
\text { width }\end{array}$ \\
\hline $\begin{array}{l}\text { Paratype, (pl. 3, figs. 1, 2) } \\
\text { Paratype, (pl. 3, figs. 5, 6) } \\
\text { Holotype, (pl. 3, figs. 9, 10) } \\
\text { Paratype, (pl. 3, fig. 11) } \\
\text { Paratype, (pl. 3, figs. 7, 8) }\end{array}$ & $\begin{array}{l}25 \\
42 \\
56 \\
61 \\
71\end{array}$ & $\begin{array}{ll}11.5 & (0.46) \\
19 . & (.45) \\
24 & (.43) \\
23 & (.38) \\
26 & (.37)\end{array}$ & $\begin{array}{lr}8.5 & (0.34) \\
20 . & (.48) \\
25 . & (.45) \\
26 . & (.37)\end{array}$ & $\begin{array}{rr}6 & (0.24) \\
11 & (.26) \\
16 & (.29) \\
19 & (.31) \\
24 & (.34)\end{array}$ \\
\hline
\end{tabular}

The ribbing of Gowericeras subitum resembles that on Eucycloceras eucychum (Waagen) ${ }^{64}$ from the Callc vian of India, and on Paracadoceras harveyi Crickmay, ${ }^{65}$ from the Callovian of the Harrison Lake area, British Columbia. However, the characteristics of the suture line and the presence of lateral tubercles a little kalow. the middle of the flanks definitely place $G$. subitum in the Cosmoceratidae. Interestingly, the three most common species of Gowericeras in the Rierdon formation are the least similar to figured species of Gowericeras in the Kellaways beds in Great Britain, although $G . s u b i$ tum shows some likeness to G. curtilobum (Buckm`n). ${ }^{66}$ Among the rarer species of Gowericeras in the Riardon formation comparisons may be made with $G$. approximatum (Buckman), ${ }^{67}$ G. planum Buckman, ${ }^{68}$ and $G$. trichophorum (Buckman). ${ }^{69}$ Associated with G. subitum are two similar species. One differs from $G$. subitum by having much coarser ribbing, particularly on the body chamber. The other differs by having fewer secondary ribs and by the gradually changing character of the ribbing. In fact, on five of the seven species the ribbing coarsens gradually rather than abruptly as on $G$. subitum. Of the seven species, only $G$. subitum is represented by immature forms which might Jave a runcinate venter. These immature forms have a flattened venter which does not make an abrupt ang's with the flanks, such as is characteristic of the early development stages of some of the species of Goweric sras in

\footnotetext{
6s Spath, L. F., Revision of the Jurassic cephalopod fauna of Kachh (Cutch) : Palaeontologia Indica, new. ser., vol. 9, mem. 2, pt. 3, p. 209, pl. 23, figs. 4a, b; pl. 25, flg. 4 ; pl. 27, figs. 7a, b, 1928.

os Crickmay, C. H., Fossils from Harrison Lake area, British Columbia : Canada Nat. Mus. Bull. 63, p. 55, pl. 16, figs. 1, 2, 1930.

Be Buckman, S. S., Yorkshire type ammonites, vol. 4, pl. 294, 1922.

o7 Buckman, S. S., op. cit., pl. 336.

\& Buckman, S. S., op. cit., pl. 287.

69 Buckman, S. S., op. cit., pl. 291.
} 
Europe. The absence or early loss of runcination sharply distinguishes the American species of Gowericeras from Kepplerites or Sigaloceras, and with the rounded whorl section, evolute coiling, and persistence of lateral tubercles show their close relationships with the European species of Gowericeras.

Holotype, U.S.N.M. 104155; paratypes, U.S.N.M. 104153, 104154, 104156a-c.

Ellis group, Rierdon formation, from 10 to 30 feet above base in Big Snowy Mountains, Fergus County, Mont. U.S.G.S. Mes. loc. 20365 , from upper 15 feet of Rierdon formation on Lonesome Ridge, Sawtooth Range near line of secs. 33 and 34 , T. 25 N., R. 9 W., Teton County, Mont.

Kepplerites (Seymourites) mclearni Imlay, n. sp.

Plate 8 , figures $1,2,5,7-10$; plate 9 , figure 1

This is the most common species in the Little Rocky Mountains; it is represented by 45 specimens, most of which are fragmentary and compressed, although the various growth stages are well shown. The immature forms have a subquadrate whorl section about twothirds as wide as high. During growth the whorls become relatively stouter, and in the adult are about five-sixths as wide as high. The flanks are somewhat flattened, becoming less so during growth. The venter is runcinate and slightly concave up to a diameter of $11 / 2$ inches (38 millimeters), and some flattening is visible up to a diameter of $2 \frac{1}{4}$ inches ( 60 millimeters). Therea fter, it changes to narrowly rounded, and on the outer whorl is moderately rounded. The umbilical wall is low, rounds evenly into the flanks, is steeply inclined on the inner whorls, and is very gently inclined on the outer whorls. The umbilicus is narrow on the smallest whorls but widens rapidly at diameters between $41 / 2$ and $51 / 2$ inches and thereafter is wide. The body chamber, including the lateral lappet, is completely preserved on the largest specimen (not figured) and is represented by $11 / 4$ volutions.

During growth the ornamentation remains persistent in character up to the body chamber. On the smaller whorls (pl. 8, figs. 1, 2, 8) the ribs are sharp and moderately spaced. The primary ribs are strong, elevated, are nearly radial, or curve backward slightly on the umbilical wall, then curve forward on the lower fourth of the flanks and terminate in prominent, conical tubercles. The secondary ribs incline gently forward, are slightly flexuous at diameters of less than $11 / 2$ inches and cross the venter transversely. Bifurcation is the common mode of branching at all growth stages, but some trifurcation occurs at diameters greater than 2 inches. Most rib branches are separated by single intercalary ribs, which begin at or slightly above the line of tubercles. During growth the ribbing gradually becomes coarse, and the tubercles remain fairly conspicuous as far as the body whorl. On the body whorl the ornamentation gradually changes. The tubercles disappear, single ribs become more common, and effacement of the ribbing occurs, especially on the lower part of the flanks. The specimen shown on pl. 8, fig. 9, has at a diameter of about $1 \frac{1}{2}$ inches (60 millimeters) 25 primary rils and about 85 secondary ribs. The holotype (pl. 9, fig. 1) at a diameter of about 8 inehes (200 millimeters) rq, 36 primary ribs and about 106 secondary ribs. At a diameter of 12 inches ( 300 millimeters) it has 68 primary ribs and 142 secondary ribs.

The suture line is deeply dissected. Ventral lobe longer than wide; first lateral lobe a little longer than ventral lobe but narrower; second lateral lobe shorter than first lateral lobe. Saddles slightly wider than lobes; ventral saddle longer than wide and divided by a lobule, which is shorter than the saddle, into a small inner branch and a large outer branch; first lateral saddle bifid, a little smaller than ventral saddle, lc nger than wide; second lateral saddle smaller than first lateral saddle, nearly as wide as long, and has its inner branch on the umbilical margin. The tubercle is in the outer branch of the second lateral saddle.

The holotype is slightly compressed. Another specimen that appears to be undistorted has at a diameter of about 9 inches (230 millimeters) a whorl height of 60 millimeters, a whorl thickness of 49 millimeters, and an umbilical width of about 175 millimeters. The small specimen shown on pl. 8, figs. 7, 9, has corresponding dimensions, of 60 millimeters, 26 millimeters, 20 millimeters and 17 millimeters.

The species is somewhat similar to $K$. gitinsi ( $\mathrm{Mc}$ Learn),${ }^{70}$ but has much coarser ribbing, fewer secondaries, more prominent tubercles, more complicated sutures, and a longer first lateral lobe. $\boldsymbol{K}$. pleras (McLearn) ${ }^{71}$ and $K$. loganianus (Whiteaves) ${ }^{72}$ have less similar ornamentation and have thicker whorl sections. The ornamentation is similar to that in Gowericeras, but the primaries are shorter, the inner whorls are much more tightly coiled, the suture is somewhat different, and the adults attain a much larger size.

Holotype, U.S.N.M. 104125; paratypes, U.S.N.M. 104122-104124, 104126-104130.

Ellis group, Rierdon formation. Mostly upper 10 to 15 feet, at many localities in the Little Rocky Morntains, Phillips County, Mont. U.S.G.S. Mes. loc. 7124, from Rierdon formation one-half to three-quarters of a mile west of Skyland, adjacent to the Great Northern

\footnotetext{
${ }^{70}$ MeLearn, F. H., Contributions to the stratigraphy and paleontolngy of Skidegate Inlet, Queen Charlotte Islands, B. C.: Canada Nat. Mus. Bull. 54, pl. 3, flg. 1 ; pl. 4, fig. 1 ; pl. 8, fig. 5, 1929.

${ }_{71}$ McLearn, F. H., op. cit., p. 5, pls. 1, 2.

72 Whiteaves, J. F. Canada Geol. Survey, Mesozoic fossils, vol. 1, pt. 1, p. 27 , pl. 8 , fig. 2,1876 .
} 
Railway at the south end of Glacier National Park, Mont.

\section{Kepplerites (Seymourites) cf. K. tychonis (Ravn)}

Plate 8 , figures $3,4,6$

A rather densely ribbed species of $\boldsymbol{K}$ epplerites, represented by a number of fragments, is herein illustrated because of its stratigraphic occurrence in beds between the zones of Gowericeras subitum and Kepplerites mclearni and because it greatly resembles $\boldsymbol{K}$. tychonis (Ravn) ${ }^{73}$ which in East Greenland characterizes a zone just above the Arcticoceras beds. The species from Montana will be provisionally referred to $K$. tychonis until more complete specimens are found, although the specimens in hand show no obvious differences. The fragments indicate a whorl section slightly higher than wide and somewhat flattened on the venter. The primary ribs are short, terminate in faint to very weak tubercles, and give rise to 2 or 3 sharp, elevated secondary ribs that incline forward gently on the flanks. On some of the larger whorls the secondary ribs incline forward rather strongly on the upper part of the flanks but cross the venter nearly transversely. The ribs are only slightly narrower than the interspaces and are much more closely spaced than in any other known species of Kepplerites from Canada or the United States.

Figured specimens: U. S. N. M. 104172, 104173.

Ellis group, Rierdon formation. (1) U.S.G.S. Mes. loc. 19629, from 23 feet above the base of the Rierdon formation on Five Mile Creek, sec. 36, T. 5 S., R. 24 E., Pryor Mountains, Mont. (2) U.S.G.S. Mes. loc. 20390, 19 feet below top of Rierdon formation on north side of Sawmill Creek, about half a mile above its mouth, near Badger Creek, sec. 3, T. 29 N., R. 11 W., Sawtooth Range, Pondera County, Mont. The formation in this area is about 141 feet thick. (3) U.S.G.S. Mes. loc. 19194, from slumped block of the Rierdon

T3 Ravn, J. P. J., On Jurassic and Cretaceous fossils from northeast Greenland : Meddelelser om Grønland, Bind 45, p. 490, pl. 37, fig. 1, 1911. Spath, L. F., The invertebrate faunas of the Bathonian-Callovian deposits of Jameson Land (East Greenland) : Meddelelser om Grønland, Bind 87 , no. 7 , pp. $83-87$, pl. 23 , figs. $1-3$; pl. 24 , figs. $2,4,6$; pl. 25, figs. $1-3$; pl. 26 , figs. $3,6,1932$. formation, 1 mile east of Autumn Creek on north side of highway, south side of Glacier Park, Mont. (4) U.S.G.S. Mes. loc. 20391, from upper part of Rierdon formation in the Northern Ordnance, Inc.-Holtz No. 1 well, sec. 23 , T. 37 N., R. 2 W., north flank of KevinSunburst Dome, Toole County, Mont. The formation is from 72 to 91 feet thick in this area ${ }^{74}$ and may linve been partly eroded before deposition of the Swift formation. ${ }^{75}$

\section{Quenstedtoceras (Bourkelamberticeras) collieri Reesid ?}

Plate 7, figures 12, 14, 15, 18

This species is represented in the Geological Survey collections by about 200 specimens that are preserved mostly as pyritized fragments and show all the grcwth stages except that of the adult. The immature forms up to a diameter of about 18 millimeters have beer described by Reeside. ${ }^{76}$ During further growth the whorl section becomes higher and subtriangular; the venter becomes slightly more narrow; the ribs become high and narrow near the umbilicus, faint near the middle of the flanks, prominent on the venter, and indistir stly united at the furcation points; the suture acquires a longer ventral lobe and a broader ventral saddle. The resulting form is similar to that of $Q$. henrici $R$. Douvillé, ${ }^{77}$ from France, but has a higher, thinner whorl section and weaker ribbing near the middle of the flanks.

Holotype, U.S.N.M. 32298; paratypes, U.S.I ${ }^{\top} . M$. 32299-32301; plesiotype, U.S.N.M. 104137.

Ellis group, Swift formation. From 25 to 30 feet above base of formation at many localities in the Little Rocky Mountains, Mont. From about 25 feet above base of Swift formation at southeast end of Bearpaw Mountains, Mont.

74 Cobban, W. A., Marine Jurassic formations of Sweetgrass arch, Mont. : Am. Assoc. Petroleum Geologists Bull., vol. 29, p. 1279, 194E'.

To Idem, p. 1289, 1290 .

7o Reeside, John B., Jr., Some American Jurassic ammonites of the Genera Quenstedticeras, Oardioceras, and Amoeboceras Family Cirdioceratidae: U. S. Geol. Survey Prof. Paper 118, pp. 14, 15, pl. 1, figs: 1-8, 1919 [1920].

${ }^{77}$ Douville, Robert, Etudes sur les Cardioceratides de Dives, V'llerssur-Mer, et quelques autres gisements: Soc. géol. France Mém. 45, pp. 55, 56, pl. 4, figs. 24-32, 1912. 
PLATES 5-9 


\section{PLATE 5}

\section{[All figures natural size]}

Figures 1-5. Defonticeras oblatum (Whiteaves) (p. 19). Ventral, lateral, and side views and last suture line of plesiotype, U.S.N.M. 104134. From 21 feet above base of Sawtooth formation at U.S.G.S. Mes. loc. 19192, north side of Swift Reservoir, sec. 27, T. 28 N., R. 10 W., Mont.

6. Gryphaea planoconvexa Whitfield (p. 17). Left valve of plesiotype, U.S.N.M. 104138. From middle part of Sawtooth formation at U.S.G.S. Mes. loc. 19619, on north wall of Indian Creek, sec. 20, T. 8 S., R. 2 E., Mont.

7, 8. Gryphaea nebrascensis Meek and Hayden (p. 18). Right and left valves of plesiotype, U.S.N.M. 104136. From upper 10 feet of Rierdon formation at U.S.G.S. Mes. loc. 19211, about 1 mile southwest of Landusky, sec. 32, T. 25 N., R. 24 E., Mont.

9-11. Gryphaea impressimarginata McLearn (p. 18). Left valves of plesiotypes, U.S.N.M. $104139 . \quad$ From basal 40 feet of Rierdon formation at U.S.G.S. Mes. loc. 18718, on Lonesome Ridge near line of secs. 33 and 34 , T. $25 \mathrm{~N}$., R. 9 W., Mont. 
GEOLOGICAL SURVEY

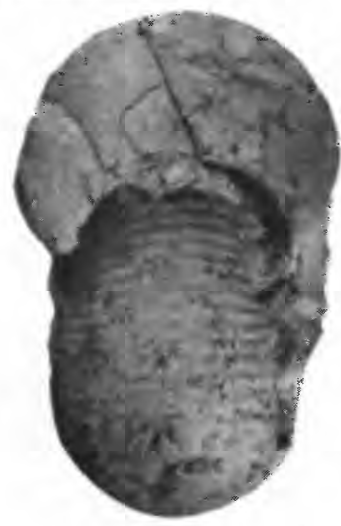

1

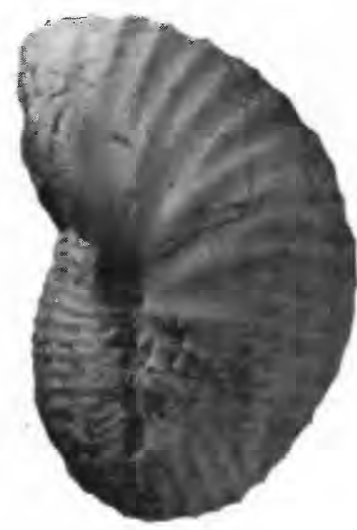

2

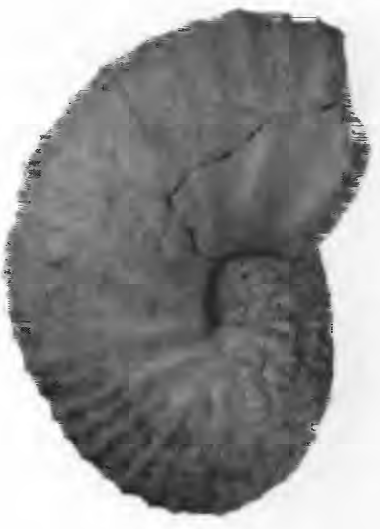

3

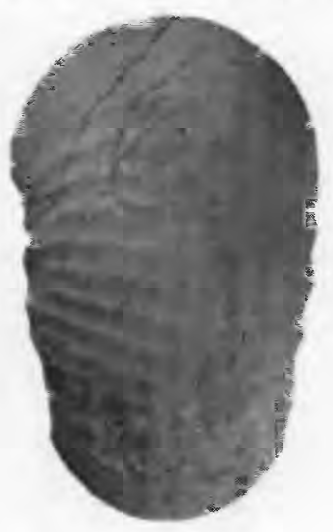

4

$$
\text { यूक }
$$

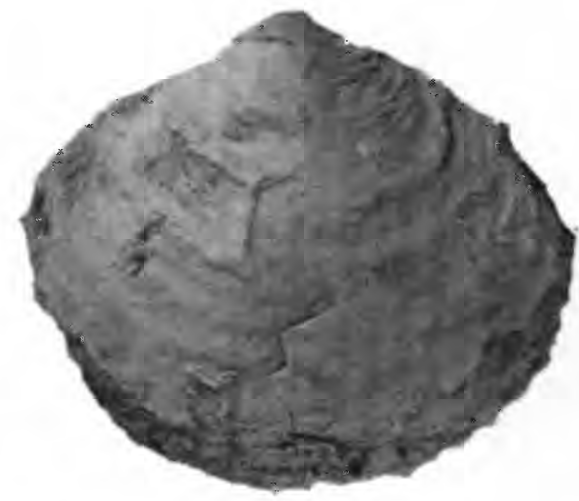

6

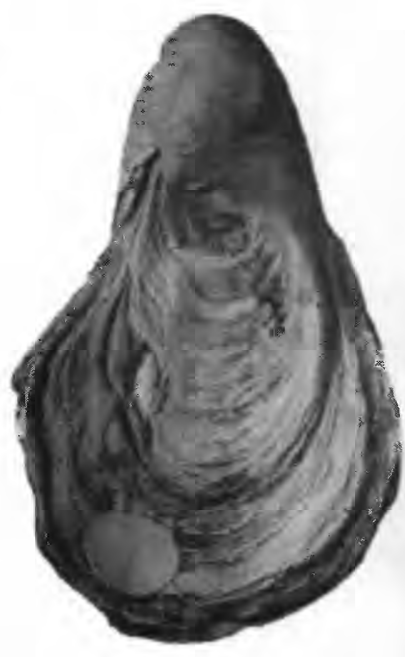

7

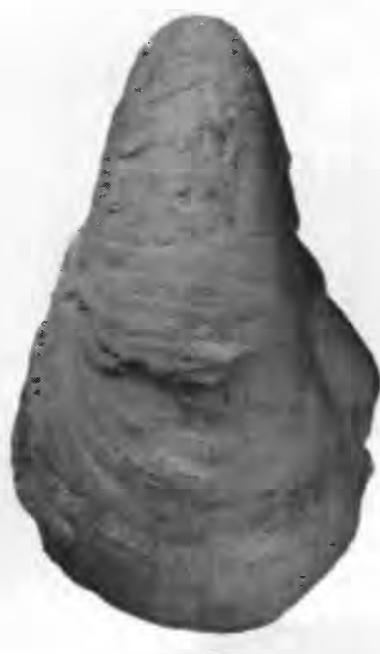

8
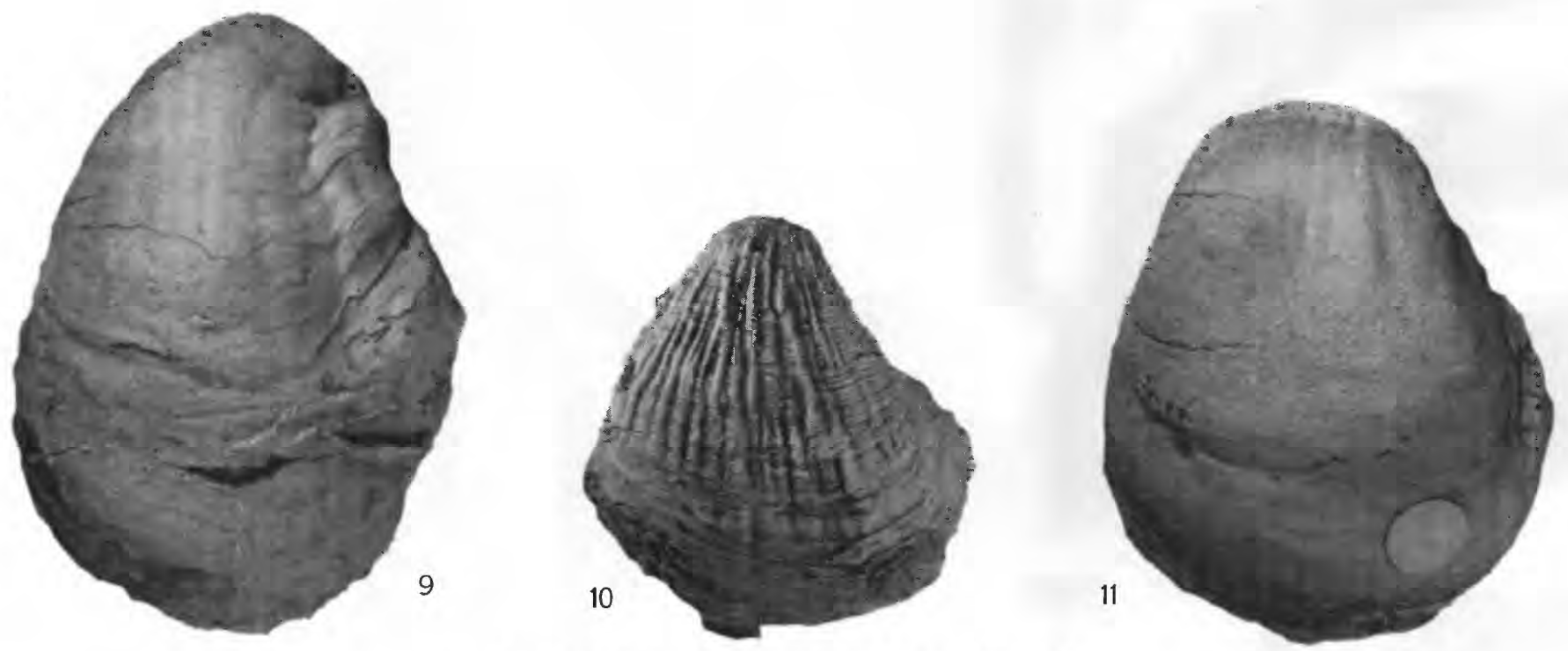

JURASSIC AMMONITE AND PELECYPODS 
GEOLOGICAL SURVEY

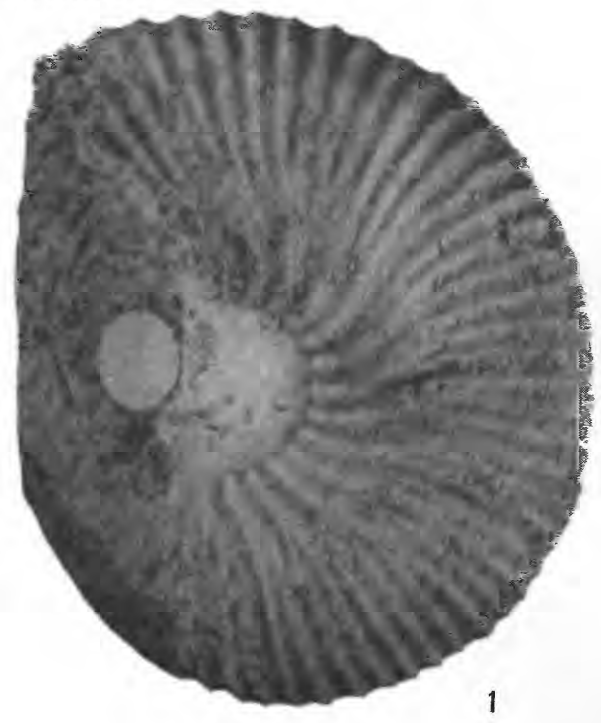

|

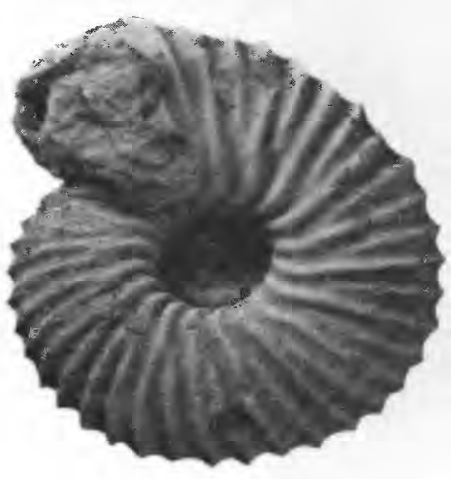

2

PROFESSIONAL PAPER 214 PLATE 6

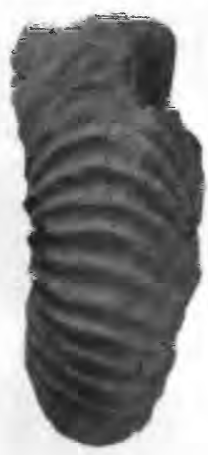

5
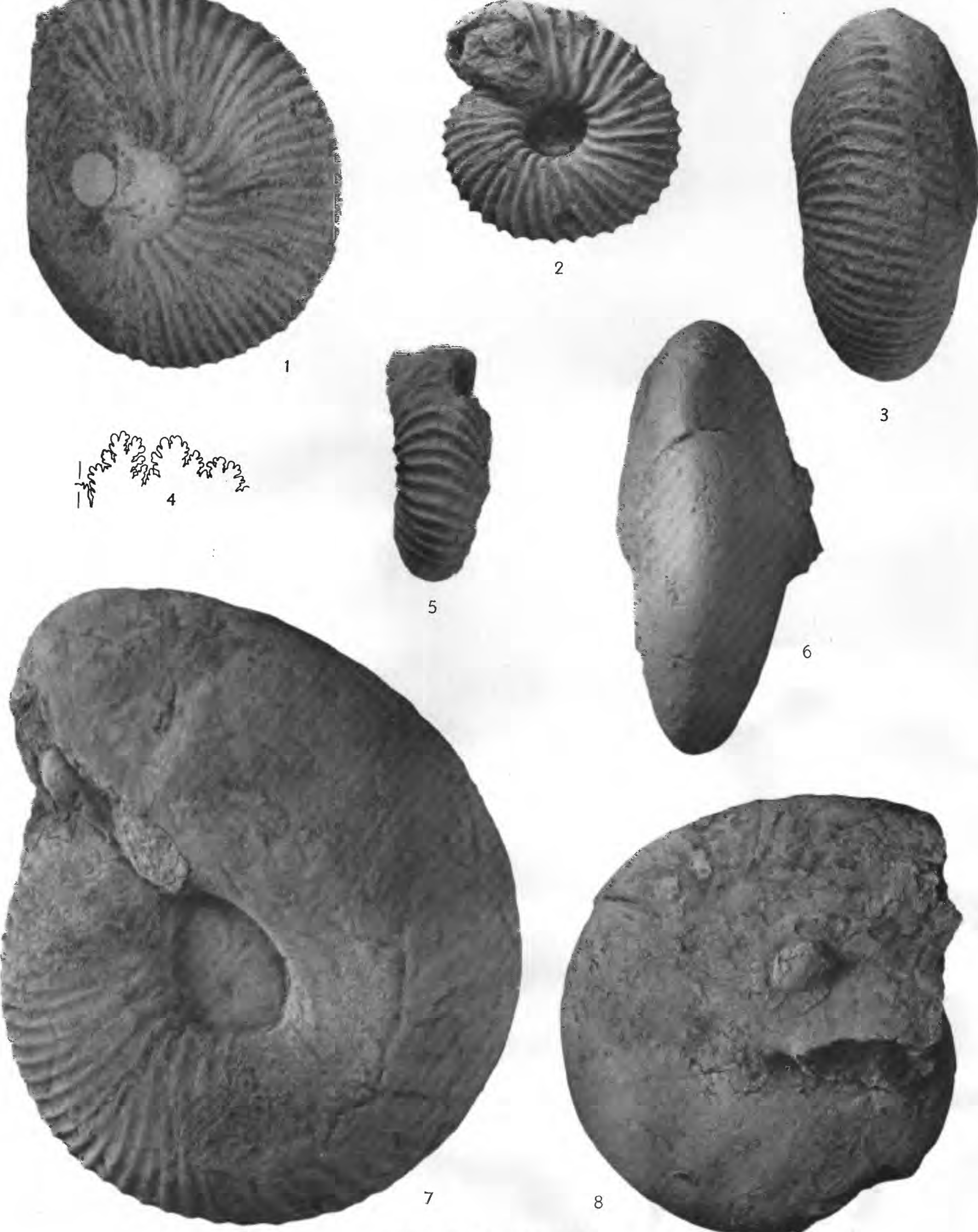

3

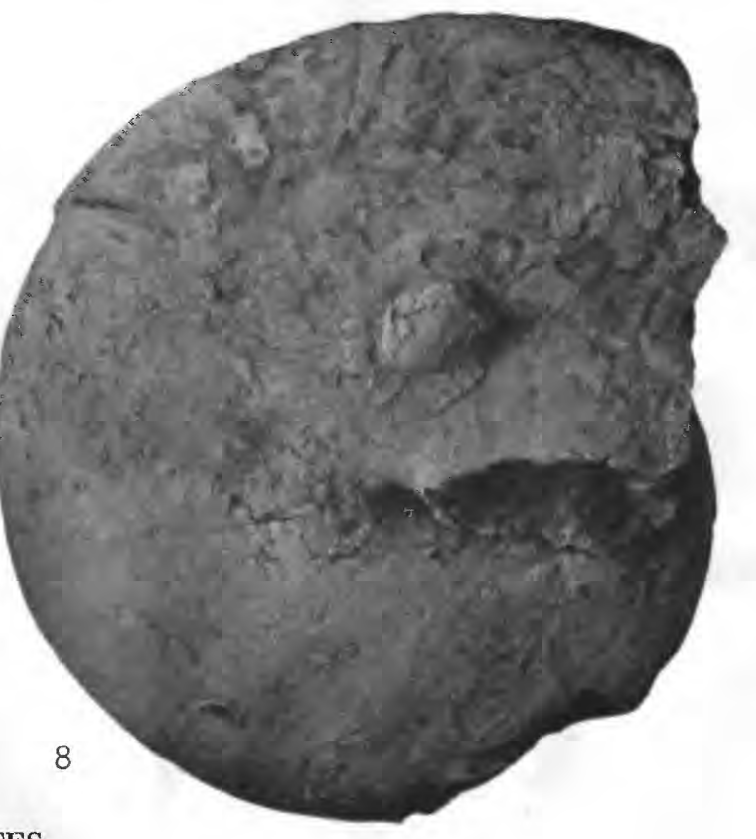




\section{PLATE 6}

[All figures natural size]

Figures 1, 3. Arctocephalites metastatus (Buckman) var. sweetgrassensis Imlay, n. var. (p. 20). Lateral and ventral views of holotype, U.S.N.M. 104150. From upper 2 feet of Sawtooth formation at U.S.G.S. Mes. loc. 19601, on Lonesome Ridge near line of secs. 33 and 34, T. 25 N., R. 9 W., Mont.

2, 5. Arctocephalites sp. juv., (f. A. suwtoothensis Imlay (p. 19). Lateral and ventral views of specimen, U.S.N.M. 104149. From U.S.G.S. Mes. loc. 18324, about 15 feet above Paleozoic rocks in lower 10 feet of silty-to-sandy nember in upper part of Sawtooth formation at head of Lime Gulch, SW1/4 sec. 1, T. 20 N., R. 9 W., Mont.

7. Arctocephalites sawtoothensis Imlaý, n. sp. (p. 19). Holotype, U.S.X.M. 104148. From U.S.G.S. Mes. Ioc. 19184. In upper 20 feet of Sawtooth formation at head of Rierdon Gulch, sec. 23, T. 24 N., R. 9 W., Mont.

4, 6, 8. Arcticoceras colyense Imlay, n. sp. (p. 20). Holotype, U.S.N.M. 104132. From U.S.G.S. Mes. 10c. 17106, in 4 feet of shaly-to-nodular limestone, 7 feet above base of Sundance formation on south bank of Shoshone River, 2 miles west of Cody, Wyo. 


\section{PLATE 7}

[All figures natural size]

Frgures 1-11. Gowericeras subitum Imlay, n. sp. (p. 22).

1, 2. Paratype, U.S.N.M. 104156a ; 4, paratype, U.S.N.M. 104156b; 5, 6, paratype, U.S.N.M. 104156c. All from U.S.G.S. Mes. loc. 19182, from upper part of an 8-foot ledge of sandy limestone 14 feet above base of Rierdon formation, 2 miles southwest of Forest Grove, sec. 21, T. 14 N., R. 21 E., Mont.

3, 11. Suture line and side view of paratype, U.S.N.M. 104153. From U.S.G.S. Mes. loc. 19169, 10 to 30 feet above base of Rierdon formation about 11/2 miles southeast of Piper, sec. 15, T. 14 N., R. 20 E., Fergus County, Mont.

7, 8. Paratype, U.S.N.M. 104154. From U.S.G.S. Mes. loc. 19180, 10 to 30 feet above base of Rierdon formation, about 1 mile southeast of Piper, SE1/4 sec. 9, and NE1/4 sec. 16, T. 14 N., R. 20 E., Mont.

9, 10. Holotype, U.S.N.M. 104155. From same locality as figures 1-6.

12, 14, 15, 18. Quenstedtoceras (Bourkelamberticeras) collieri Reeside (p. 25). Plesiotype, U.S.N.M. 104137. From U.S.G.S. Mes. loc. 19577, 25 to 30 feet above base of Swift formation at southwest end of Coburn dome, Little Rocky Mountains, sec. 33, T. 25 N., R. 26 E., Mont.

13, 16, 17. Cadoceras shoshonense Imlay, n. sp. (p. 22). Last suture line and lateral and ventral views of holotype, U.S.N.M. 104143. From U.S.G.S. Mes. loc. 17179, 4 feet of nodular sandy limestone, 15 feet above base of Sundance formation on south bank of Shoshone River, 2 miles west of Cody, Wyo. 
PROFESSIONAL PAPER 214 PLATE 7

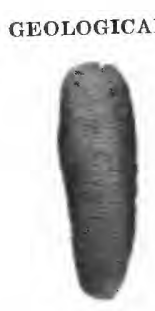

1
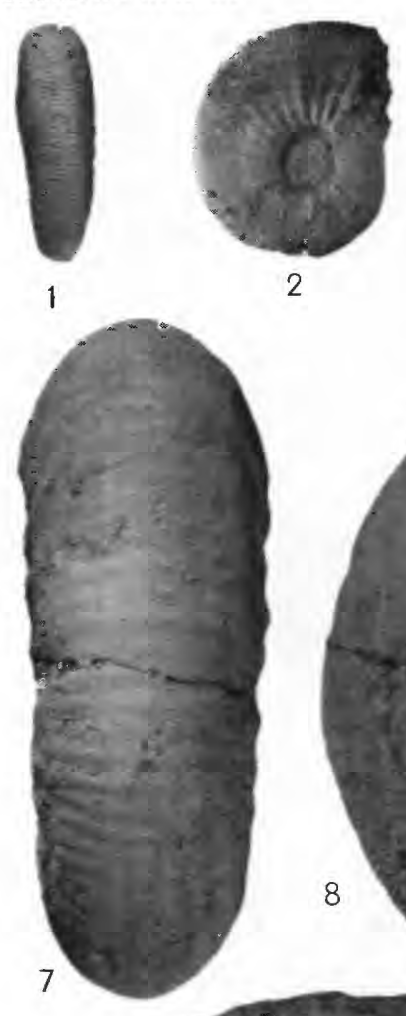

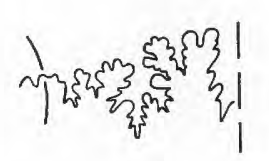

3
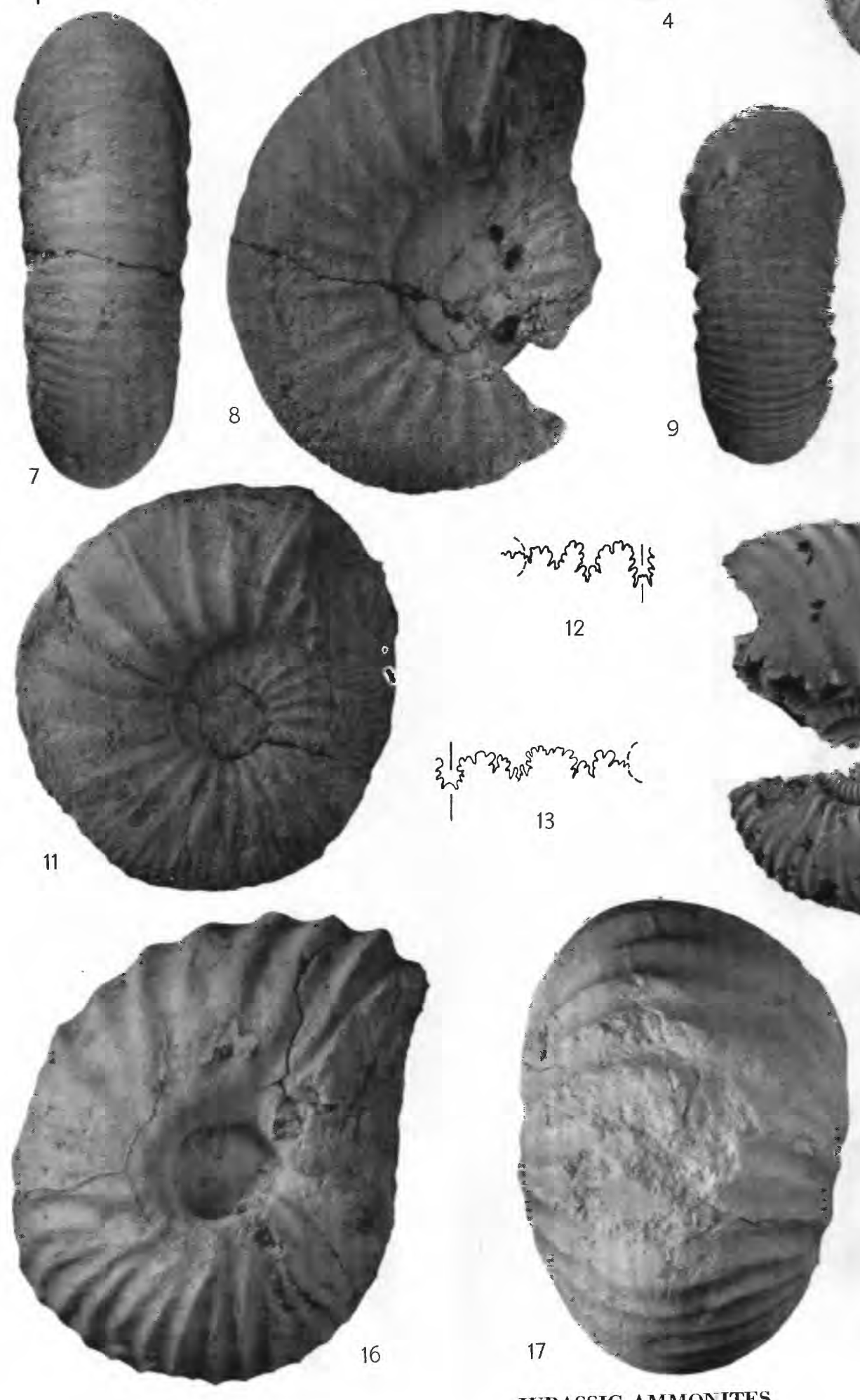

JURASSIC AMMONITES
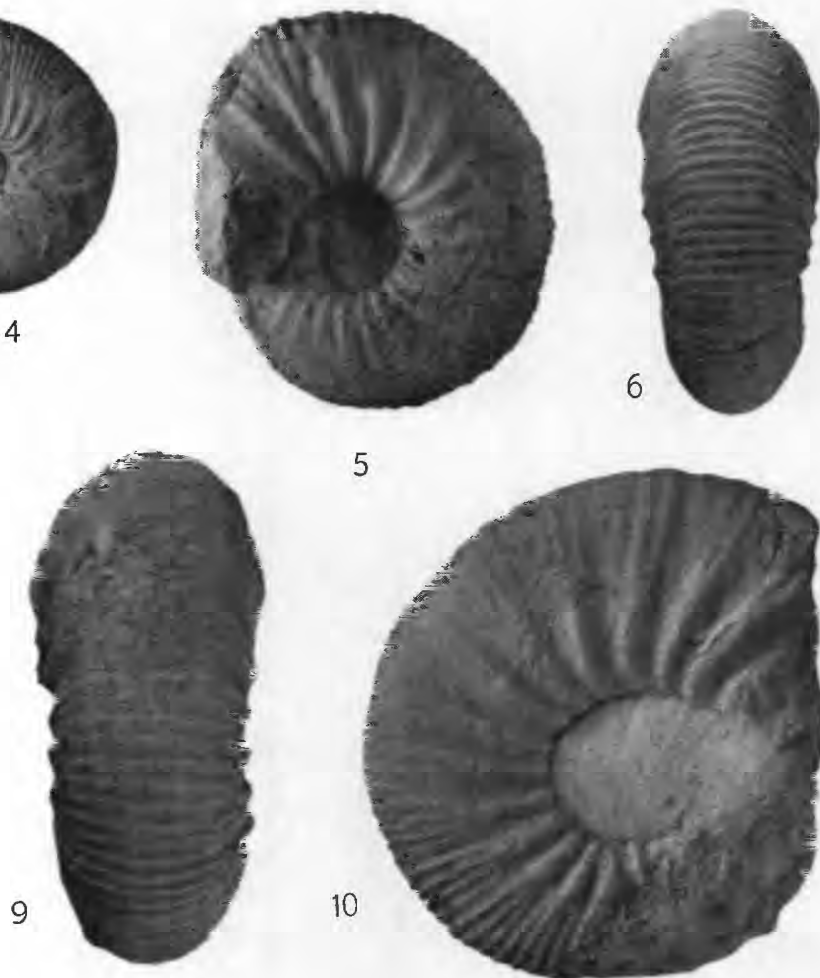

5

10

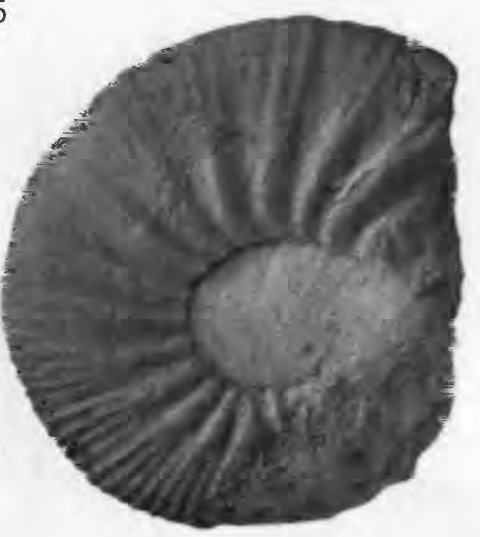

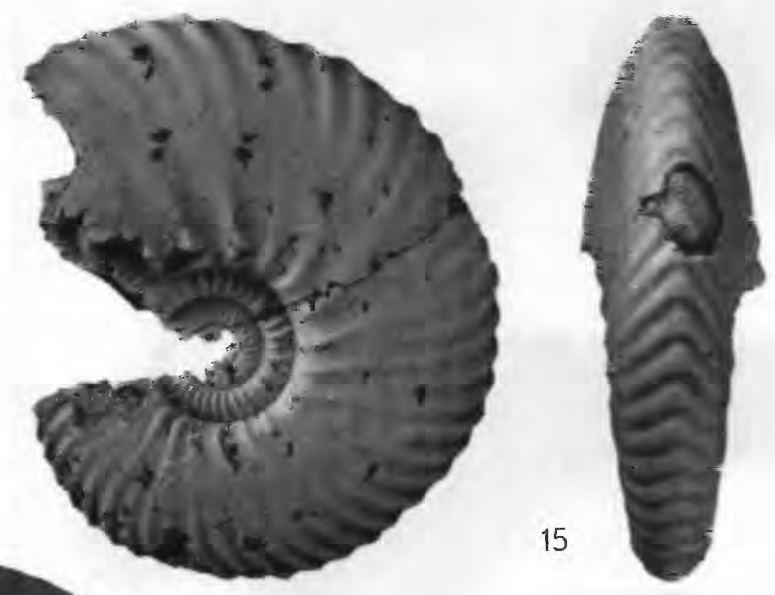

14

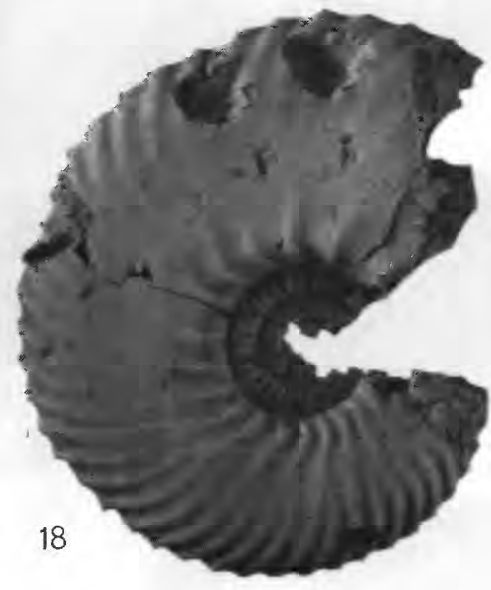


GEOLOGICAL SURVEY

PROFESSIONAL PAPER 214 PLATE 8
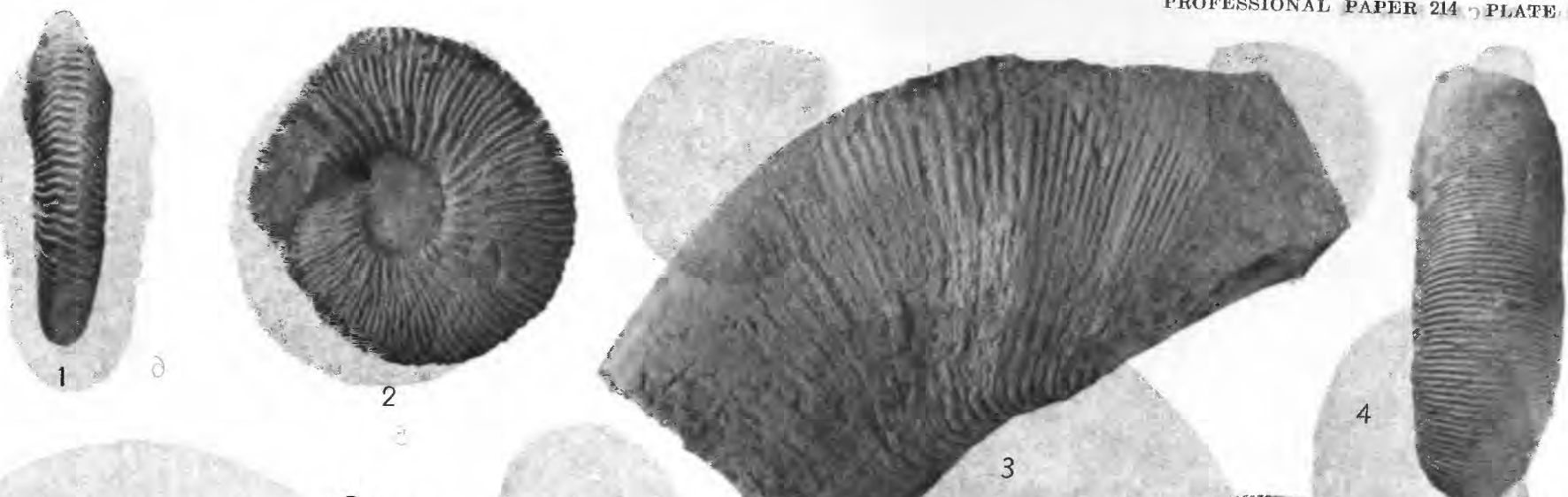

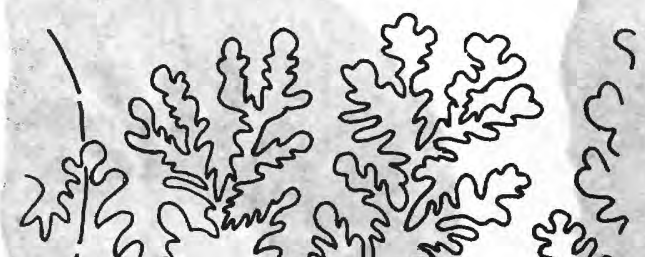

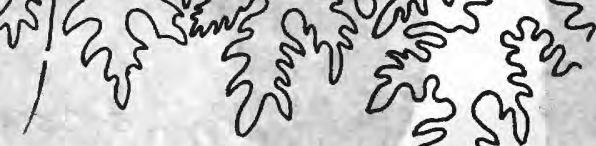
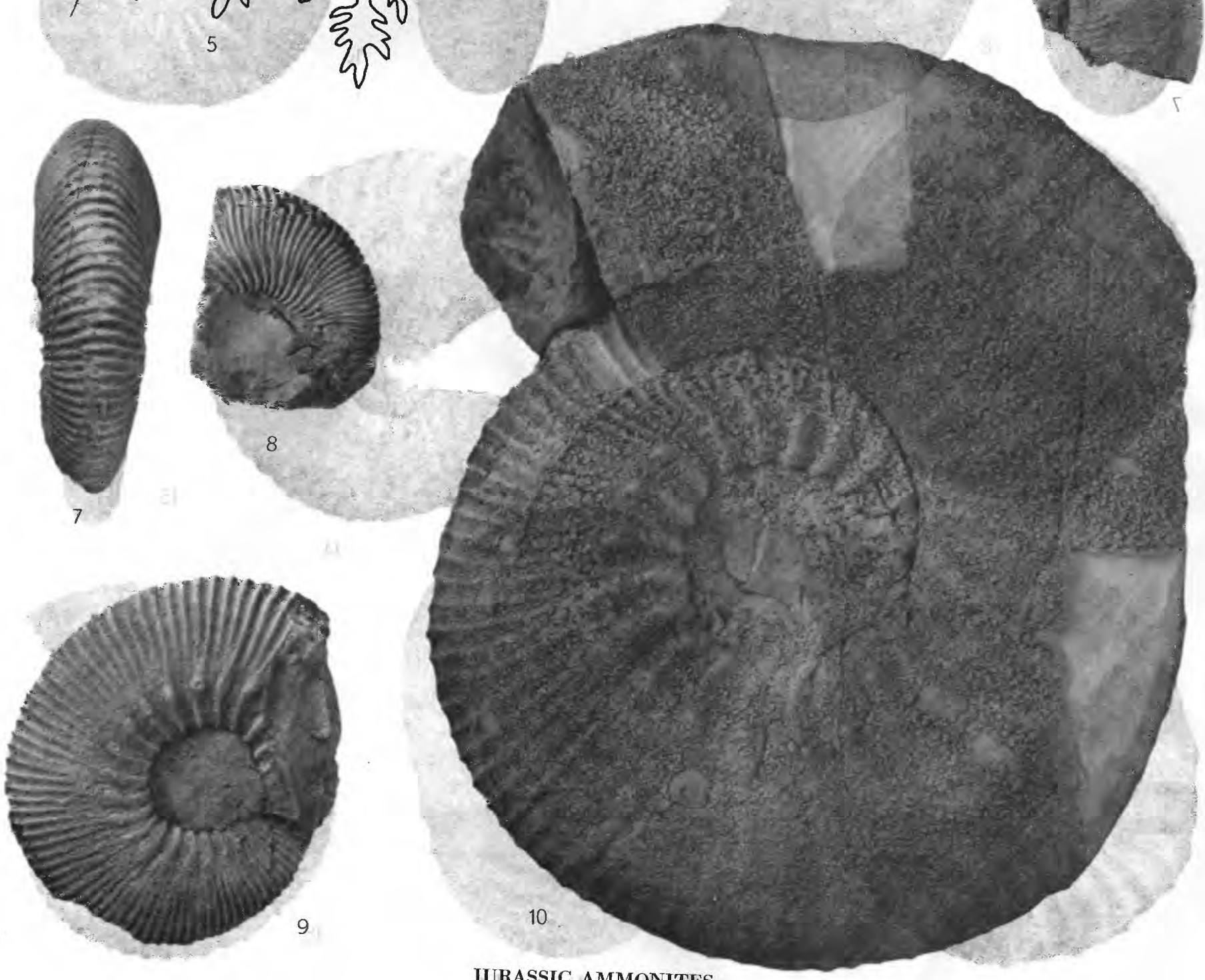

JURASSIC AMMONITES 


\section{PLATE 8}

[All figures natural size]

Figures 1, 2, 5, 7-10. Kepplerites (Seymourites) mclearni Imlay, n. sp. (p. 24).

1, 2. Paratype, U.S.N.M. 104126. From U.S.G.S. Mes. loc. 19583, in upper 10 feet of Rierdon formation, south side of Camp Creek dome, Little Rocky Mountains, sec. 6, T. 24 N., R. 26 E., Mont.

5. Suture line of paratype, U.S.N.M. 104122. From U.S.G.S. Mes. loc. 10732, east slope of mountain south of Zortman, Little Rocky Mountains, Mont.

7, 9. Paratype, U.S.N.M. 104128. From U.S.G.S. Mes. loc. 10732, east slope of mountain south of Zortman, Little Rocky Mountains, Mont.

8. Paratype, U.S.N.M. 104127. From U.S.G.S. Mes. loc. 19584, in upper 10 feet of Rierdon formation on east side of Matador dome, sec. 3, T. 25 N., R. 26 E., Phillips County, Mont.

10. Paratype, U.S.N.M. 104123. From U.S.G.S. Mes. loc. 18737, in upper part of Rierdon formation, NW11/4 sec. 3 , T. 25 N., R. 26 E., Mont.

3, 4, 6. Kepplerites (Seymourites) cf. $K$. tychonis (Ravn) (p. 25).

3. Lateral view of a fragment, U.S.N.M. 104172. From U.S.G.S. Mes. loc. 20390, about 19 feet below top of Rierdon formation on north side of Sawmill Creek about half a mile above its mouth, sec. 3, T. 29 N., R. 11 W., Pondera County, Mont.

4, 6. Ventral and lateral views showing mouth border of specimen, U.S.N.M. 104173. From U.S.G.S. Mes. loc. 19629, about 23 feet above base of Rierdon formation on Five Mile Creek, sec. 36, T. 5 S., R. 24 E., Mont. 


\section{PLATE 9}

[All figures two-thirds natural size]

FIGdre 1. Kepplerites (Seymourites) mclearni Imlay n. sp. (p. 24). Holotype, U.S.N.M. 104125. From U.S.G.S. Mes. loc. 19211, in upper 10 feet of Rierdon formation, about 1 mile southwest of Landusky, sec. 32, T. 25 N., R. 24 E., Phillips County, Mont. 


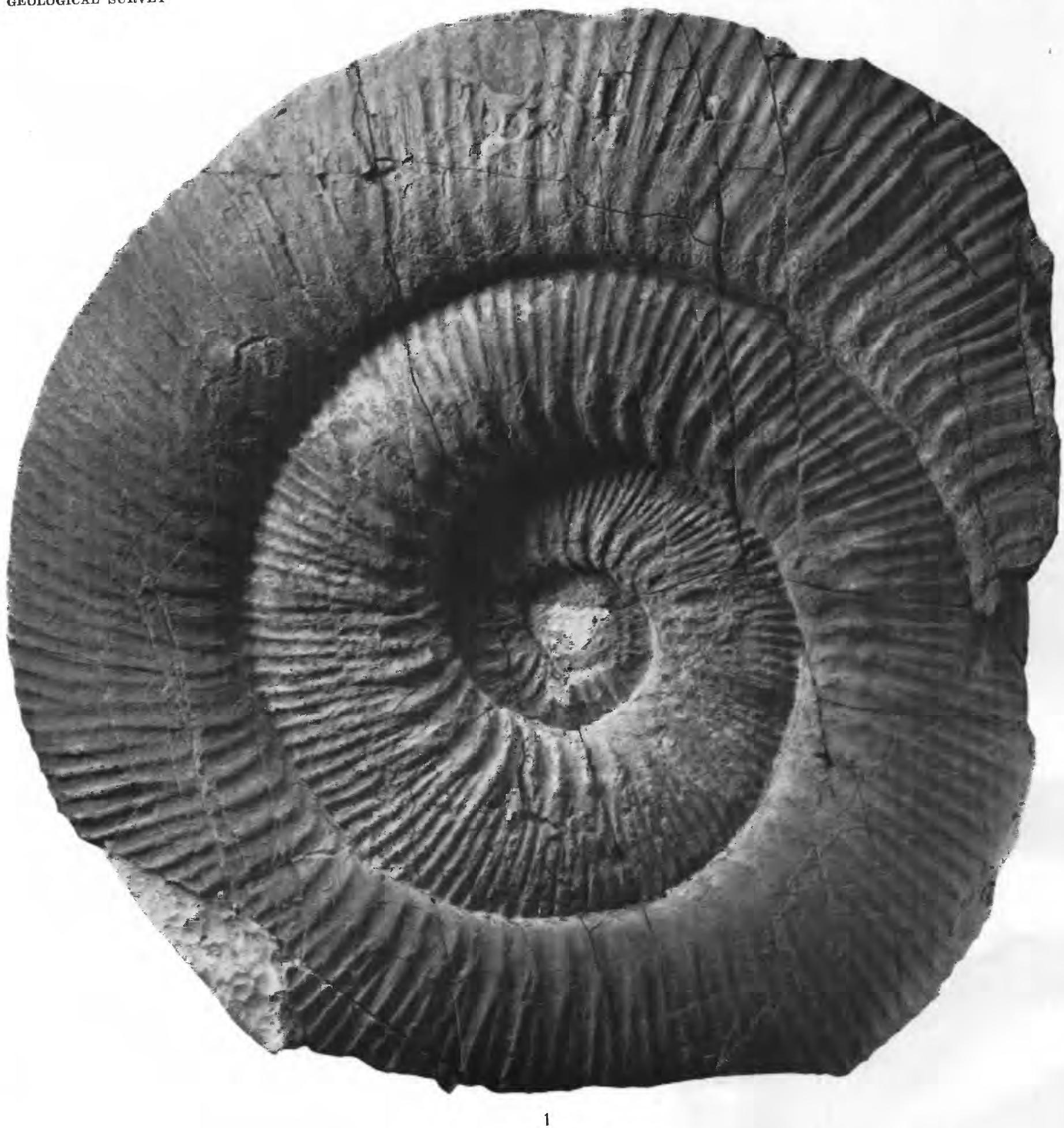

JURASSIC AMMONITE 


\section{INDEX}

Page

Abstract.

Ammonites loganianus (?) Form A

Arcticoceras codsense

henryi__._.

ishmae _.

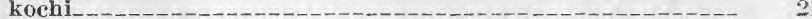

Arcticoceras zone_____

Arctocephalites arcticus______._. 20

elegans _._.

ellipticus _._.

metastatus sweetgrassensis

sawtoothensis__._.

Arctocephalites zone

Cadoceras freboldi

shoshonense

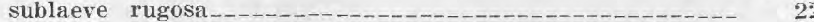

tschernyschewi _._._. 22

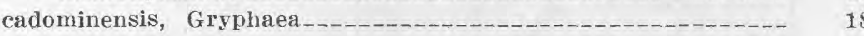

Cardioceras cordiforme zone____ 17

codyense, Areticoceras_____ collieri, Quenstedtoceras (Bourkelamberticeras)_..........- 25; pI. 7

Defonticeras oblatum____

Defonticeras-Stemmatoceras zone__.___._.

Dolikephalites typicus ...

Fucyelocerus eucyclum 23

Faunal zones and correlations_..._.

Gowericeras approximatum_ 23

- curtilobum _- 23

planum _... 23

subitum _..

trichophorum

.23

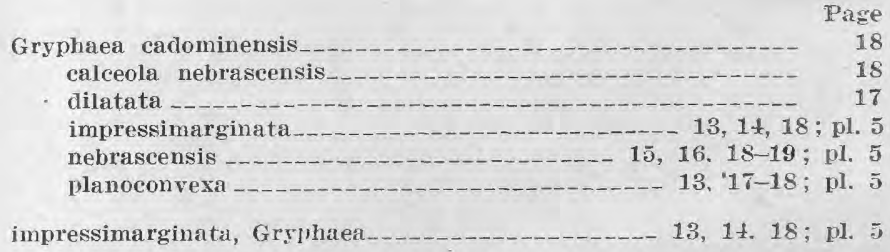

Kamptokephalites hedfordensis____... 20

Kepplerites gitinsi

loganianus _...

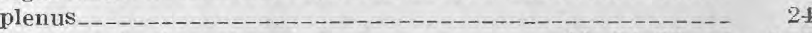

(Sermourites) melearni__.___......_. 16, 24-25; pls. \&, \& tychonis _..... 16, 25: pl. 8

mclearni, Kepplerites (Seymourites) _______16, 24-25: pls. 8, 9 Macrocephalites ishmae _._._._. 21

"Metacephalites" metastatus_______ 20

"Miccocephalites" laminatus 19

nebrascensis, Gryphaea____. 15, 16. 18-19; pl. 5

oblatum, Defonticeras___.

Paracadoceras harveyi planoconvexa, Gryphaea__...

Quenstedtoceras henrici _..._.

(Bourkelamberticeras) collieri__._._._._._. 16-17, 25; pl. 7

sawtoothensis, Arctocephalites shoshonense, Cadoceras____

Stephanoceras oblatum____ 19 subitum, Gowericeras___________. 15-16, 22-24; pl. 7 sweetgrassensis, Arctocephalites metastatus__._._._._ 20: pl. 6

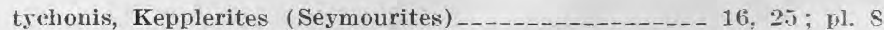

Zemistephanus vancouveri 